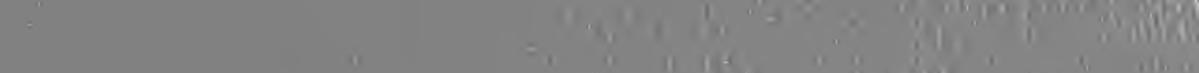

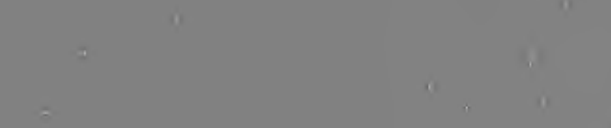

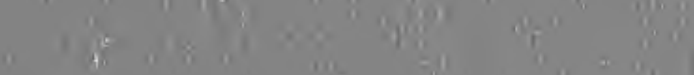

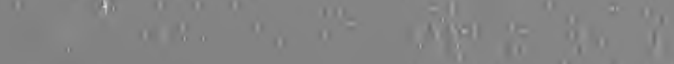

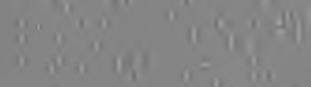

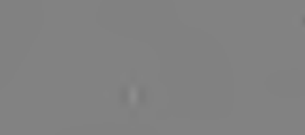

0

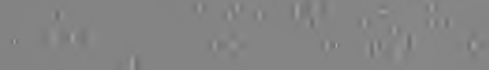
$a$

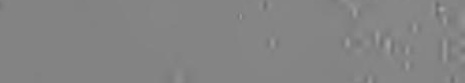

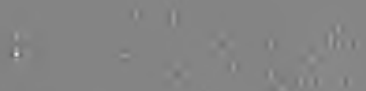

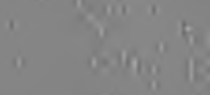

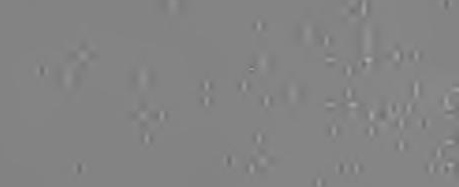

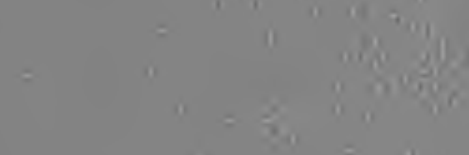

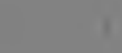

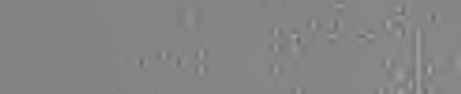

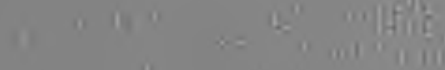

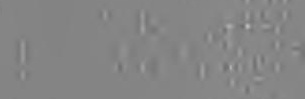

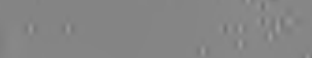
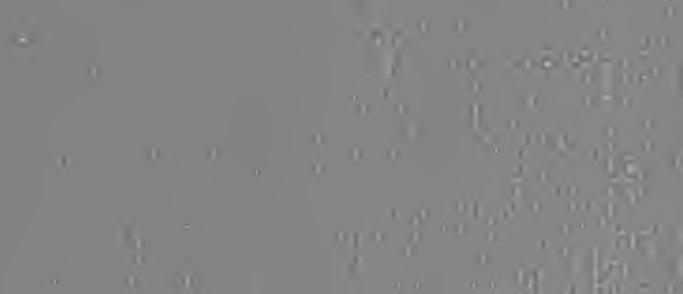

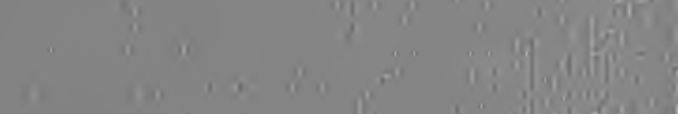

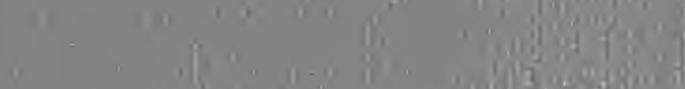
" $\therefore$ "

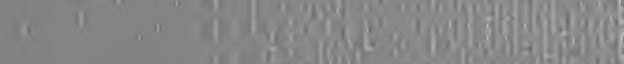




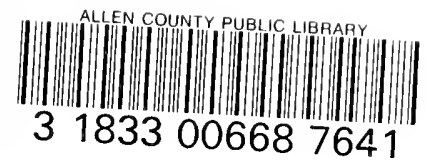




\section{Digitized by the Internet Archive in 2010 with funding from Allen County Public Library Genealogy Center}






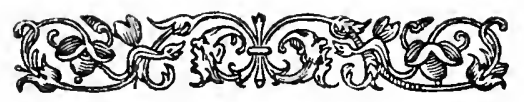

THE ARMY LISTS OF THE ROUNDHEADS

AND CAVALIERS.

\& 



\section{THE}

\section{ARMY LISTS OF THE ROUNDHEADS}

\section{AND CAVALIERS,}

CONTAINING THE NAMES OF THE OFFICERS IN

THE ROYAL AND PARLIAMENTARY

ARMIES OF 1642 .

EDITED BY

EDWARD PEACOCK, F.S. A.

"An epoch rich alike in thought, action, and paffion, in great refults, and ftill greater beginnings."

MARGARET FUlLER OSSCli.

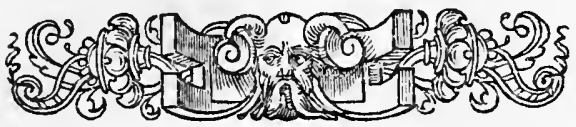

LONDON :

JOHN CAMDEN HOTTEN, PICCADILLY.

1863. 
<smiles>[C]1C=CC=C1</smiles> 


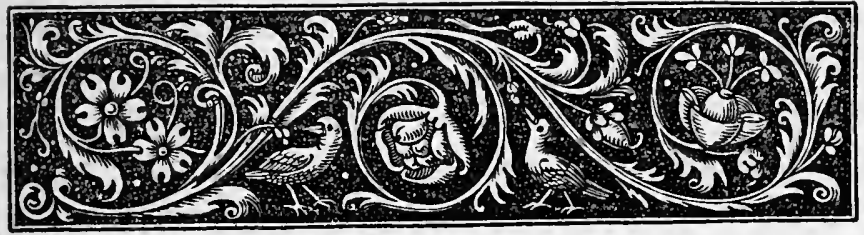

1315315

PREFACE.

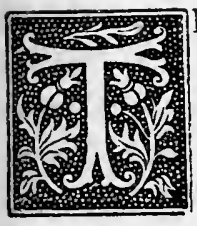

HOSE who have ftudied that period of our annals which is occupied by the reign of Charles the Firft and the Commonwealth, not only in the pages of modern hiftorians and contemporaries who wrote confcioufly for pofterity, but alfo in the immen $\int e$ maffes of unclaffified and often uncatalogued documents, journals, ftate papers, letters, treatifes, ballads, and fermons, in which the hopes, fears, and defires of the people expreffed themfelves from day to day, may probably have remarked, if their purfuits have led them to contraft our Civil War with other portions of Britifh or European hiftory, that then, for the firft time in the modern world, individual perfonality began to exercife a marked effect upon contemporary politics. In the preceding ages, from the time indeed when freedom funk under the organized imperialifm of the Cxfars, until the outburft of modern thought in the fixteenth century, human progrees had been but little accelerated by perfonal qualities. The ignorance of external nature was too den $\int e$, the allpervading influence of the dominant theology too ftrong, the terrors it wielded and the punifhments it threatened too frightful for the energy of any one perfon to become confpicuous in directing public 
events or moulding the thoughts of others, except in tho fe rare cafes where the minds of men had already been prepared by the Church's teaching, or by their inherent or inherited fuperftitions. In the career of Saint Bernard indeed, and the few others of his ftamp, who fhed fuch luftre over the dark times in which they were placed, we fee the religious inftinct of Weftern Chriftendom ftirred to a higher pitch of devotion by the labours of a fingle man; but where the leffons of the reformer took a direction contrary to ecclefiaftical teaching, (and then theology feemed to embrace the whole area of human thought,) one refult only was poffible. The fate of thofe who ftruggled to win freedom for them felves and their kind is a jufficient proof that it was neither the want of intellect, energy, nor highfouled devotion, that rendered their lives and labours unfruitful. Even the paffionate prophecy and withering $\int$ corn of the great Florentine could do nothing towards roufing mankind from its lethargy. The firft defire of his heart was indeed accomplifhed; Dante won for his Beatrice the higheft place in the ideal world of love and beauty, but againft the "She-wolf" even the invectives of the "Inferno" were powerle $\int$ s.

The education of the European mind has progre fed flowly; it was not until the Tudor period of our hiftory that fociety could have exifted without the protection of a powerful religious cafte. A univerfal theocracy was the only inftitution ftrong and free enough to curb the oppreffor, and with a fufficiently extended mental vifion to attempt the work of legiflation: by its means the brutal tyranny of the feudal lord was fomewhat kept in check ; and his fiercer paffions, at leaft, did not pafs entirely without rebuke. Laws were made for the protection of flaves, infants, and women, fuch as even a Norman baron or an Italian count feared to difobey. It does not feem poffible that moral truths could have been brought home to the hearts of the people by any other means. If $\int 0$ great a misfor- 
tune could have happened as the premature overthrow of this $\int$ piritual dominion it is almoft certain that a fimilar inftitution, or one differing in outward accidents only, would have taken its place. And if it had not been fo, the people would have lapfed into mere pagan $\int \mathrm{en} \int u a l i \int \mathrm{m}$; a compound of Teutonic materialifm and Southern creature-wor/hip without the noblene $s$ of the one or the poetry of the other.

The great religious contefts of the fixteenth century, while they relea fed the races of Northern Europe from Jubjection to one cla $\sqrt{s}$ of ideas which they had outgrown, left almoft everything to be accomplifhed in the direction of perfonal freedom. It is doubtful whether any of thofe engaged on either fide in that memorable ftrife even underftood what is now meant by liberty.

The fingularly complex nature of our political and focial relations on the accelfion of the Stuart dynafty tended greatly to develope individual energies, and thus to produce that marked contraft between the Civil-War era and all preceding ones, which is perhaps the moft interefting phenomenon prefented by that memorable conteft. Probably no defcendant of the Plantagenets, then alive, was more unfitted to rule England than the weak perfon whom political necelfity forced upon us on the death of the noble-minded Elizabeth. It would have taxed the higheft energies of a wife and brave fovereign to have governed a land fo diftracted with religious factions with dignity and in peace. James poffelfed neither courage nor wifdom, but had the abfence of thofe virtues been his chief defect, his reign might have caufed le $\int s$ evil. His political bigotry, mitigated as it was in action by his extreme cowardice, was not calculated to produce the worft refults; but unfortunately, like many other feeble-minded men, he took intenfe delight in theological fpeculation. As the head of the eftablifhed religion in England it was the obvious duty of the chief magiftrate to make that body as little 
offenfive to the people as the nature of $\int 0$ fingular a compromife would admit of ; but, from influences which it probably would be ea $\int y$ to trace to their origin, the king's mind was bent upon purfuing an oppofite courfe. The extreme nature of the religious factions into which his realms were divided, Jpurred on the zeal of the theologian not to be a minifter of peace but an enforcer of uniformity. The Catholics, who had received in the early part of the reign fome flight mercy, when the monarch found himfelf Jufficiently powerful to do fo, were perfecuted with unrelenting feverity. The increafing body of Puritans (a defignation which muft be underftood to include perfons of nearly all varieties of opinion who were oppofed to de $\int$ potifm in the ftate and extreme Epi $\int$ copalian views on Church government) hated the ruling powers almoft as intenfely as did their brethren of the Roman obedience, and with nearly as good reafon ; for, although they were not fubject to capital punifhment, like the members of the ancient faith, their lives were rendered miferable by ftate tyranny. The Puritans, certainly had not, at firft, any ftrong feelings againft monarchical power when reftrained within due bounds, - fome, indeed, profeffing to the laft their defire for " a covenanted King," but they naturally became, as time wore on, le $\int \mathrm{s}$ and le $\int s$ attached to the exifting order of things. It is probable that a ftrong-willed and unprincipled monarch might have played off the $\int e$ factions againft each other with confiderable perfonal advantage. It is evident that James endeavoured to do fo, and as he had at times able minifters about him, it is not unlikely that even he might have fucceeded had England been his only kingdom; Scotland and Ireland happily prefented unfurmountable obftacles to the crufhing out of either of the $\int \mathrm{e}$ religious bodies. The northern kingdom was entirely Puritan; the Catholic Church in that region had not merely fallen,-its members had been fo hunted down by their fucceffors, that hardly an avowed profeffor of the old religion 
was to be found. Epifcopacy, indeed, was ftill fuppofed to exift, but its frange and unedifying hiftory was fo well known, that we cannot fuppofe it appealed very forcibly to the confciences of any but thofe dependent on government patronage. On the other hand, Ireland had clung with the tenacity of defpair to the medixval form of Chriftianity - it was the only thing that connected her with the far off' paft, that carried back the memories of her poor perfecuted children to times when they had at leaft one powerful protector on earth from the opprefion of their conquerors. This padionate attachment decked the mythic paft with the rainbow tints of unreal beauty, it became part of an Irijhman's faith that his country had once had a golden age of peace, profperity, and virtue; under the mild guardianfhip of the Church of God.

The attempts made to convert the $\int e$ kingdoms to the King's views were too weak to produce any effect except irritation; but they muft be borne in mind in calculating the forces which produced the revolution that followed.

Charles was a far nobler man than his father; had he ruled in other times he might have left a favourable impreffion on pofterity ; in the circumftances in which he was placed his higher qualities were almoft entirely hidden. Whether it was by force of hereditary tranfmifion, or the refult of education, that Charles reJembled James cannot now be known, but the fame weak nature is remarkable in the child as in the parent,- the fame obftinacy, the fame theological inftincts with even le $\int \mathrm{s}$ diftruft of his own power of enforcing conviction, and a greater affection for the mechanical parts of religious worfhip. His faith in the fanctity of his own office was probably more fincere than his father's. It was dangerous in proportion to its fincerity.

The hiftory of the political and religious ftruggles of the fe reigns, of the forty years' battle for liberty, fought with varying fuccess at 
Weftminfter when there was a parliament at the Council Board, in the law-courts and the fhires when the king ruled alone, has come down to us in a very unattractive form. The various leaders have as yet had but little juftice done to their memories, the more obfcure men have quite paffed out of memory. Let us remember that to them we owe much of what followed both of good and evil.

The long conteft, ere an appeal to arms was thought of, prepared Englifh minds for felf-government, and fhook to its bafe that belief in the holine $\int s$ of the kingly office, which the Reformation had foftered, and which Jubfequent events had developed into an article of faith. Ere the war of words was $\int \mathrm{u} \int$ pended by a fterner conflict, I believe that among the mass of the people, the dream of the divine right of kings had palfed away for ever. A figment fuch as that once Shattered could never be reftored, even the faturnalia of the

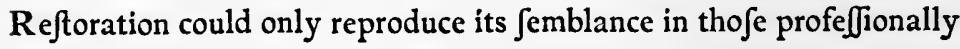
interefted. The cry-

\section{"Cæfar in urbe fuâ Deus eft,"}

found no echo in men's hearts. If the reader wifhes to hear it, and is not to be deterred by bla $\int$ phemy or filth, let him read the fermons of the court-preachers and the rhyme-books of the court-poets.

It is not my intention, in this reprint of a Civil-War tract, to trace, even in the mereft fkeleton manner, the hiftory of the period. A word or two feems, however, to be required to account for the appearance of this little book. I have long been making collections relative to the lives of thofe perfons who were engaged on both fides during the Great Civil War. In the work I have in progre $\int \mathrm{s}$ I fhall include, as far as polfible, every officer who bore a commiffion from King or Parliament, and many other perfons who rendered them $\int$ elves confpicuous in the convulfions of the time. Of cour $\int e$ I fhall not omit to give a place to the many noble women alfo who fuf- 
fered on either fide. It will be readily underftood that although the work in queftion will be made as concife as is polfible, confiftently with communicating the faEts of the various lives, it is yet a laborious undertaking, which cannot be brought to a conclufion for fome years.* It was, however, Juggefted to me by my publifher that a reprint of the following Army Lift would be welcomed by many ftudents as a handy work of reference in reading contemporary hiftorians. Its ufefulnefs to thofe engaged in topographical and genealogical ftudies is evident. To fuch a book it was perhaps unneceffary to add notes; I have, neverthelefs, for the convenience of the general reader, given a line or two of biographical memoranda to the names of moft of thofe perfons who rendered themfelves prominent. To have enlarged them further fo as to include the more obfcure would have been but to anticipate very imperfectly a future publication. The trakt, of which the following pages are a reprint, is preferved in the Bodleian Library. I never faw another copy, but I believe one or two more exift; it is, however, of extreme rarity. The lift of the Earl of Efex's army is to be found alfo in a Jeparate pamphlet, with which this edition has been compared. A reprint of its title-page occurs here in the proper place.

Although the date 1642 occurs on the title, it is certain that this Lift was not iffued until that year had, according to modern computation, clojed. It will be borne in mind, however, that the legal year in the feventeenth century begun on the 25th of March, the feaft of the Annunciation of the Bleffed Virgin Mary, and that therefore a book iffued from the prefs before that day in the year

- I take this opportunity of afking for affiftance in my labours on the biography of the Civil-War. The completenefs of the work depends materially on the amount of information I am able to procure from local fources. The loan of Civil War tracts or any other documents relating to the period will be a great help to me. 
1643 would bear the date of the previous year. The occurrence of Philip Skippon, as "Serjeant Major General and Prefident of the. Councill of War," is decifive on this point. * It is not fo eafy to account for the name of "Sir Faithful Fortefcue" being retained in the lift of the Parliament's army.

My especial thanks are due to Monfieur J. A. Van Lennep of Zeyft, near Utrecht, for a long and extremely interefting communication relative to Dr. Doreflaus which I have ufed in the note attached to that perfon's name. I have a melancholy pleafure alfo in exprefling my obligations to the late Rev. John Ward, of Wath Rectory, near Ripon.

E. P.

Bottesford Manor, near Brigg,

December I 5, 1862 .

- Clarendon's Hiftory of the Rebellion, royal 8vo. 1843, p. 382. 


\section{A

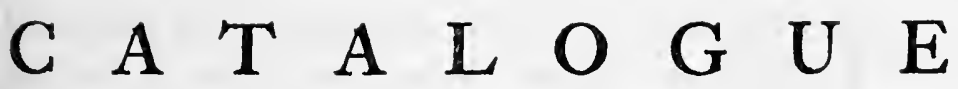

OF THE NAMES OF

\section{THE DUKES, MARQUESSES,}

EARLES and Lords, that have abfented themfelves from the Parliament, and are now with His Majefty. And of the Names of the Lords that Subscribed to levie Horfe to adift his Majeftie with A Copie of all the Cavaliers of his Majefties Marching Army with the number of Captaines in each Jeverall Regiment ; every Regiment containing a thoufand Souldiers.

As alfo, a lift of the Army of his excellency, Robert Earle of EJjex: With the names of the Troops of Horfe under the Command of William Earle of Bedford. Each Troop confifting of fixtie Horfe; befides two Trumpetters, three Corporalls, a Sadler, and a Farrier. With the Inftructions fent by the Parliament to his Excellency.

A lift of the Navie Royall, and Merchant Ships: the Names of the Captaines and Lievtenants ; their men and burdens for the Guard of the Narrow-feas, and for Ireland.

Moreover, the Names of Orthodox Divines, prefented by the Knights and Burgefes as fit perfons to be confulted with by the Parliament touching the Reformation of Church Government and Liturgie.

Laftly The Field Officers chofen for the Irifh Expedition, for the Regiments of 5000 Foote and 500 Horfe.

Printed i642. 



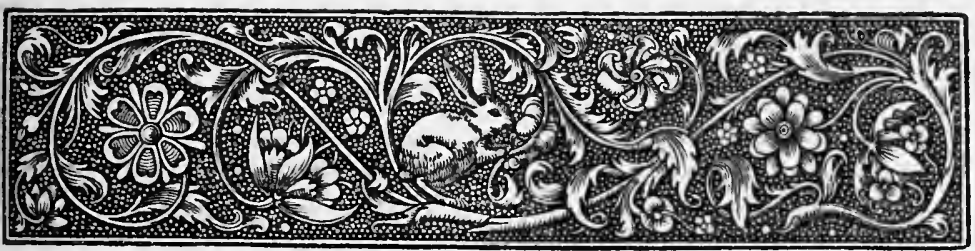

\section{A CATALOGUE OF THE NAMES OF}

\section{THE DUKES, MARQUESSES, EARLES AND LORDES, THAT}

HAVE ABSENTED THEMSELVES FROM THE

PARLIAMENT, AND ARE NOW

WITH HIS MAJESTIE.

The Lord Keeper. ${ }^{1}$

Duke of Richmōd. ${ }^{2}$
Marque je of Hertford. ${ }^{3}$

Marqueffe Hamilton. ${ }^{4}$

1 Edward Lyttelton, fon and heir of Sir Edward Lyttelton, of Henley, co. Salop, Knt. Born 1589 ; educated at Chrif Church, Oxford ; M.A. I609; D.C.L. I642; Recorder of London; Solicitor General, O\&t. 17, 1634; knighted June 6, 1635; Chief Juftice, Jan. 27, 1639; Lord Keeper of the Great Seal, Jan. 23, I640; created Baron Lyttelton, of Mounflow, co. Salop, Feb. I8, 1640 ; joined King Charles I. at York, 1642 ; a Privy Counfellor and Colonel of a foot regiment at Oxford. Died at Oxford, Aug. 27, 1645; buried in Chrift Church.-Wood's Athena Oxon. Jub nom. Lloyd's Memoires, p. 582. Nicholas's Hifforic Peerage, 1857.

${ }^{2}$ James Stuart, fecond Earl of March in the peerage of England, and third Duke of Lenox in Scotland. Created Duke of Richmond, Aug. 8, 1641; K.G. Died, 1655. He was one of the four noblemen who were permitted to be prefent at "their mafter's burial."-Life of Clarendon, i 843, p. 1049.

${ }^{3}$ William Seymour, created Marquefs of Hertford, June 3, 1640. Reftored to the title of Duke of Somerfet, I660; K. G. Died, I660. He alfo was one of the four peers who witneffed the burial of Charles I.

4 James Hamilton, Marquefs and afterwards Duke of Hamilton in the peerage of Scotland; fecond Earl of Cambridge in the peerage of England. Beheaded by the Commonwealth, March 9, 1649 . 
Earle of Cumberland. ${ }^{5}$

Earle of Bathe. ${ }^{6}$

Earle of Southampton. ${ }^{7}$

Earle of Dorfet. ${ }^{8}$

Earle of Salifbury. ${ }^{9}$

Earle of Northampton. ${ }^{10}$
Earle of Devonfhíre. "

Earle of Carlile. ${ }^{12}$

Earle of Clare. ${ }^{13}$

Earle of Weftmorland. ${ }^{14}$

Earle of Monmouth. ${ }^{15}$

Earle of Lindfey. ${ }^{16}$

${ }^{5}$ Henry Clifford, fifth Earl. Died, 1643 .

${ }^{6}$ Henry Bourchier, fifth Earl. Died, 1654. "A great fcholar ..... always afferting the king's intereft, attending him in his counfel in York, and his general in his affairs in the Weft, till being taken prifoner, $16_{42}$, when he was rendered uncapable of ferving his king and kingdom, he grew weary of the world, paying for his loyalty $900 l . "-$ LLOYD's Memoires, p. 650.

"They took prifoner the Earl of Bath in Devonhire, who neither had, or ever meant to do the king the leaft fervice ; but only out of the morofity of his own nature, had before, in the houfe, expreffed himfelf not of their mind."Clarendon's Hif. 1843 , p. 297.

7 Thomas Wriothelley, fourth Earl of Southampton. Succeeded as fecond Earl of Chichefter, 1653 . Died, 1667 . He was one of the four noblemen who were prefent at the funeral of King Charles I. Created K. G. at the Reftoration.-CLarendons Life, p. ro49.

${ }^{8}$ Edward Sackville, fourth Earl. Killed Lord Bruce in a duel beneath the walls of Antwerp, $161_{3}$. Died, " 17 th of July, 1652 , and had fepulture with his anceftors at Withiam."-Collins's Peerage, 1735, vol. i. p. 443.

9 William Cecil, fecond Earl. K.G. Died, 1668.

10 Spenfer Compton, fecond Earl, "was, born at Compton, in Warwickrhire, the very fane day and hour that the Powder Traytors were defeated at Dunchurch, in that County."-LLOY D's Memoires, p. 353. Slain at Hopton Heath, co. Stafford, March Igth, I643; buried in All Hallows Church, Derby.

11 William Cavendifh, third Earl. Died, 1684.

12 James Hay, fecond Earl. Died, 1660.

13 John Holles, fecond Earl. Died, 1665.

14 Mildmay Fane, fecond Earl. Died, February 12, 1665; buried at Apethorp, co. Northampton.

${ }^{15}$ Henry Carey, fecond Earl. Died, $\mathrm{I} 66 \mathrm{I}$.

${ }^{16}$ Robert Bertie, tenth Baron Willoughby de Erenby. Created Earl of Lindfey, Nov. 22, 1626 ; Lord Great Chamberlain ; K. G.; Lord High Admiral, 1636 ; Governor of Berwick, 1639 ; General of the King's forces at the breaking out of the civil war. Mortally wounded at the battle of Edge Hill, Ost. 23, 1642, aged 60 years; buried at Edenham, co. Lincoln.-AlLEN's Hiff. of LincolnBire, vol. ii. p. 295. 

Earle of Newcaftle. ${ }^{17}$
Earle of Dover. ${ }^{18}$
Earle of Carnarvan. ${ }^{19}$
Earle of Newport. ${ }^{20}$

Earle of Thanet. ${ }^{21}$

Lord Moubray. ${ }^{22}$

Lord Strange. ${ }^{23}$

Lord Willoughby. ${ }^{24}$

"At Edgehill that was true of him and his Countreymen, the Loyal Gentry of Lincolnhire, that was obferved of Cataline and his followers: That they covered the fame place with their Corpfes when dead; where they ftood in Fight, whilft living."-LLoxD's Memoires, p. 3 I4.

17 William Cavendifh. Created Earl of Newcaftle, March 7, 1628; Duke of Newcaftle, 1664. K.G. Died, 1676 .

${ }_{18}$ Henry Carey, fourth Baron Hundfon. Created Earl of Dover, March 8, 1628. Died, 1668.

19 Robert Dormer, fecond Baron Dormer. Created Earl of Carnarvon, Aug. 2, 1628. Slain at the firt battle of Newbury, Sept. 20, 1643. His jewels and plate were feized by the Parliamentary army while on their way to Oxford. He was run through the body by a trooper to whom he was perfonally known. When afked if he had any fuit to make to the king ere he paffed away, the dying cavalier replied :- "I will not die with a fuit in my mouth to any king fave to the King of Heaven."

${ }^{20}$ Montjoy Blount. Created Earl of Newport, in the Inle of Wight, Aug. 3, 1628. Died, 1665.

${ }^{21}$ John Tufton, fecond Earl. Died, 1664.

${ }^{22}$ Henry Frederick Howard, fon and heir of Thomas Howard, Earl of Arundel. Summoned to the Houfe of Peers during his father's life, April 13, 1639, as Baron Mowbray. He fucceeded to his father's earldom in 1646 .

${ }^{23}$ James Stanley, fon and heir of William Stanley, Earl of Derby. Summoned to the Houfe of Peers during his father's life ; fucceeded to his father's earldom in 1642 . He was defeated at the Battle of Wigan-Lane, co. Lancafter, by Col. Robert Lilburne, but fucceeded in joining King Charles II. at Worcefter, after whofe rout there, Sept. 3, 1651, he fled with him into Staffordhire. Taken prifoner at Newport, in Cherhire, by Colonel Edge, tried by court martial, and beheaded at Bolton, in Lancahire, October 15,1651 . The timber of the fcaffold on which he fuffered is faid to have been a relic from Lathom Houfe.

24 Montague Bertie, fon and heir of Robert Bertie, Earl of Lindfey; fum-moned to Parliament during his father's life as Baron Willoughby; K. G.; Lord Great Chamberlain. Died, 1666 . Commanded the Royal Guards at Edge Hill. He was one of the four peers who faw the body of King Charles buried at Windfor, and endeavoured, ineffectually, to difcover its refting-place after the Reftoration. 
Lord Longavill. ${ }^{25}$

Lord Rich. ${ }^{26}$

Lord Andover. ${ }^{27}$

Lord Faulkconbridge. ${ }^{2 s}$

Lord Lovelace. ${ }^{29}$

Lord Paulet. ${ }^{30}$
Lord Newarke. ${ }^{31}$

Lord Coventry. ${ }^{32}$

Lord Savill. ${ }^{33}$

Lord Dunfmore. ${ }^{34}$

Lord Seymor. ${ }^{35}$

Lord Capell. ${ }^{36}$

${ }^{25}$ Charles Longueville, fon and heir of Sir Michael Longueville and Sufan Gray, his wife, fifter of Henry Gray, eleventh baron Gray of Ruthin, and eighth Earl of Kent. Claimed and was allowed the barony of Gray in 1640 . He is called Lord Longueville to diftinguifh him from his contemporary, Sir Thomas Gray, called Lord Gray of Grouby, the fon and heir of Henry Gray, fecond Baron Grey of Grouby, who was created Earl of Stamford, co. Lincoln, I 628 , and from William Gray, firf Lord Gray of Werke.-Nicholas's Hiftoric Peerage, I 857.

Lord Gray of Ruthin died, at Oxford, of fmall-pox, June 7, 1643; buried in All Hallows Church.-Dugdale's Diary, edited by Hamper, fub die.

${ }^{26}$ Robert Rich, fon and heir of Robert Rich, fecond Earl of Warwick. Succeeded to the Earldom of Warwick, 1658 . Died, 1659 .

${ }^{27}$ Charles Howard, fon and heir of Thomas Howard, firft Earl of Berkfhire. Summoned to Parliament in the life of his father, as Baron Howard of Charlton; fucceeded to his father's Earldom, 1669 . Died, 1679.

${ }^{28}$ Sir Thomas Belafyfe, Bart. firft Lord Fauconberg of Yarm, co. York. Created Vifcount Fauconberg of Henknowle, co. Durham, Jan. 3r, I643. Died, 1652 .

${ }^{29}$ John Lovelace, fecond Baron. Died, 1670.

${ }^{30}$ John Poulett, firft Baron Poulett of Hinton St. George, co. Somerfet. Died, 1649 .

31 Henry Pierrepoint, fon and heir of Robert Pierrepoint, the firft Vifcount, who was created Earl of Kingfton-upon-Hull, July 25, I628; and was flain in action, July 30,1643 , during his paffage in a pinnace from Gainfborough to Hull as a prifoner of war. Henry Pierrepoint died in 1680 .

${ }^{32}$ Thomas Coventry, fecond Baron Coventry of Aylefborough, co. Worcefter. Died, I66r.

${ }^{33}$ Thomas Savile, fecond Baron. Created Vifcount Savile, in the peerage of Ireland, I628; Earl of Suffex, 1644. Died, I67x.

34 Sir Francis Leigh. Created Baron Dunfmore of Dunfmore, co. Warwick, 1628. Earl of Chichefter, r644. Died, 1653.

${ }^{35}$ Francis Seymour, firft Baron Seymour of Trowbridge, co. Wilts. Died, 1664 .

${ }^{36}$ Arthur Capel. Created Baron Capel of Hadham, co. Hertford, Aug. 6, 


\section{A CATALOGUE OF THE NAMES OF THE LORDS THAT}

SUBSCRIBED TO LEVIE HORSE TO ASSIST

\section{HIS MAJESTIE.}

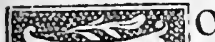

O pay horfes for three Moneths, thirty dayes to the Moneth, at two fhillings $\int \mathrm{ix}$ pence per diem, ftill advancing a Months pay, the firft payment to begin fo foone as the King fhall call for it after the Commiffions fhall be iffued under the Great Seale. In this Number are not to be reckoned the Horfes of the Subfcribers, or thofe that $\int$ hall attend them.

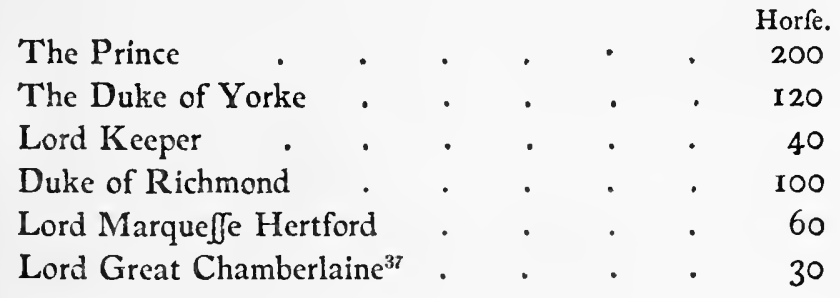

x641. Beheaded by the Commonwealth for defending Colchefer, March 9, 1649; buried at Hadham, co. Hertford. His arms were Gules, a lion rampant between three crofllets fitchée, or. In allufion to which, after his death, this diftich became current :-

\section{" Our Lion-like Capel undaunted ftood Befet with croffes in a fea of blood."}

There is a "pleafant ftory" in Clarendon concerning Lord Capel's miffion from King Charles I. to the Earl of Kingiton to borrow money, which gives an amufing picture of the times.

${ }^{37}$ Robert Bertie, tenth Baron Willoughby de Erefby and Earl of Lindfey. See Note $\mathbf{r} 6$. 
Earle of Cumberland . . . . . 50

Earle of Huntington $^{38}$. . . . . 20

Earle of Bath . . . . . . 50

Earle of Southampton . . . . . 60

Earle of Dorfet . . . . . . . 60

Earle of Northampton . . . . . 40

Earle of Devonfhire . . . . . 60

Earle of Dover . . . . . . 25

Earle of Cambridge . . . . . . 60

Earle of Briftoll ${ }^{39}$. . . . . . . 60

Earle of Weftmerland . . . . . 20

E. of Barkfhire and L. Andover ${ }^{40}$. . . 30

Earle of Monmouth . . . . . 30

Earle Rivers $^{41}$. . . . . . . 30

Earle of Carnarvan . . . . . 20

Earle of Newport . . . . . 50

Lord Mowbray $\quad$ • $\quad . \quad$. $\quad$ • 50

Lord Willoughby $\quad$. . . . 30

Lord Gray of Ruthin ${ }^{42}$. $\quad$. . . . 10

38 Henry Haftings, fifth Earl. Steward of the Duchy of Lancafter, and Lord Lieutenant of the counties of Leicefter and Rutland. Died, Nov. 1643.

39 John Digby. Created Earl of Briftol, Sept. 15,1622. Ambaffador extraordinary to Spain to negotiate the contemplated marriage of Prince Charles with the Infanta ; interceded with James I. for indulgence to Roman Catholics. A commiffioner to treat with the Scots at Ripon, 1640. Among the propolitions tendered by the Lords and Commons to the $\mathrm{King}$ in 1643 , the fixth was:" That the Earl of Briftol may be removed from your majefty's councils."Clarendon's Hift. p. 338 . Died, 1653

10 Thomas Howard, firft Baron Howard of Charlton and Vifcount Andover. Created Earl of Berkfhire, Feb. 7, 1626; K. G. A commiffioner to treat with the Scots at Ripon, 1640. "The government of that hopeful and excellent Prince [afterwards Charles II.] was committed to the Earl of Berkfhire for no other reafon but becaufe he had a mind to it, and his importunity was troublefome."-Clarendon's Hift. p. 455. Died, r669.

41 John Savage, fecond Earl. Died, 1654.

${ }_{2}$ See note 25. 
Lord Lovelace

Lord Paget ${ }^{43}$

Lord Faulconbridge to come

Lord Rich . . . . . . . 30

Lord Pawlet .. . . . . . 40

Lord Newarke $\quad . \quad$. $\quad . \quad . \quad . \quad . \quad 30$

Lord Mountague $^{44}$. . . . . 30

Lord Coventrey . . . . . . 100

Lord Savill . . . . . . . 50

Lord Mohun ${ }^{45}$. . . . . . 20

Lord Dunfmore . . . . . . 40

Lord Seymor . . . . . . 20

Lord Capell . . . . . . 100

Lord Faulkland ${ }^{46}$. . . . . 20

Mafter Comptroller ${ }^{47}$. . . . . 20

Mafter Secretary Nicholas ${ }^{48}$. . . 20

${ }^{43}$ William Paget, fifth Baron. Died i 9 th Oetober, 1678 . Buried at Drayton, co. Middlefex. He was the perfon who read in the Houfe of Lords the charges of the Scotch Commiffioners againft Archbifhop Laud, I640.-OLDMIXON's Hiftory of the Stuarts, p. 159.

44 Edward Montagu. Created Baron Montagu of Boughton, co. Northampton, 29 June, 162x. When upwards of eighty years of age he was committed to the Tower by the Parliament, where he died, 1644.

${ }^{45}$ Sir John Mohun, Bart. Created Baron Mohun of Okehampton, co. Devon, ${ }_{5}$ A pril, r628. Died, 1644 .

${ }^{46}$ Lucius Carey, Vifcount Falkland of Falkland, co. Fife, in the Peerage of Scotland. Slain at the Battle of Newbury, Igth September, i643.

${ }^{47} \mathrm{Sir}$ Peter Wych had been ambaffador to Conftantinople, from whence he returned but a flort time before the breaking out of the Civil War. Clarendon fays he was " a very honeft plain man." He died at Oxford, $5^{\text {th }}$ December, r643, and was buried in Chrift Church Cathedral.-Dugdale's Diary, fub. die. Arms, azure, a pile ermine.

${ }^{48}$ Edward Nicholas. Made Secretary of State after Secretary Windebank fled abroad, $164^{\circ}$. 
Lord Chiefe Juftice Banks ${ }^{49}$. . . 20

The Lord Thanet is not here but one hath undertaken for 100 for him

Sum. totall. 1695 .

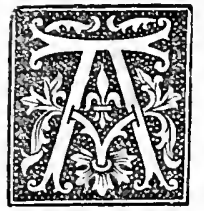

COPY of a Lift of all the Cavaliers of his Majefties Marching Army, with the number of Captaines in each feverall Regiment, and every Regiment containing about a thoufand Souldiers.

\section{IMPRIMIS I REGIMENT.}

The Earle of Newcaftle Lord Generall of His Majejties foot Forces.

Lievtenant Colonell Rich.

Sergeant Major Babthorpe.

Captaine Fleetwood. ${ }^{50}$

Captaine Waters.
Captaine Hemings.

Captaine Acton.

Captaine Gyles.

Captaine Fifher.

Captaine Andrewes. ${ }^{51}$

Captaine Froft.

${ }^{49}$ Sir John Banks, born at Kefwick. Knighted, ift Auguft, 1634. One of the Privy Council at Oxford, where he died, 28th December, 1644. Buried in Chrift Church. See his epitaph in Wood's Hiftory of Oxford. Sir John Banks was the hurband of the gallant lady who defended Corfe Caftle:

so William Fleetwood, afterwards a colonel in the Royal Army. Son of Sir William Fleetwood of Aldwinkle, co. Northampton, cupbearer to James I. and Charles I, and Comptroller of Woodftock Park. He was half brother to George Fleetwood and Charles Fleetwood the Parliamentary officers. Arms, parted per pale, nebule azure and or, fix martletts counter-changed.

${ }^{51}$ Eufebius Andrews was fecretary to Lord Capel, educated for the Law, withdrew from the Royal Army, I645. Tried by a Court of High Commiffion and beheaded for high treafon againt the Commonwealth, $165^{\circ}$. 
2 Regiment.

Collonell Lord Taffe an Irijhman. ${ }^{52}$

Lievtenant Colonell Sir John Rodes.

Serjeant Major, Thomas Treveere.

-Captaine Upton.

Captaine Hobbey.
Captaine White

Captaine Hill.

Captaine Farryer.

Captaine Whiteacre.

Captaine Floyd.

Captaine Douglas.

Captaine Winter.

\section{Regiment.}

Collonell Haftings. ${ }^{5: 3}$

Liev. Collonell Langley. Sergeant Major Stanley.

Captaine Fryer.
Captaine Venner.

Captaine Hodges.

Captaine Johnfon.

Captaine Fifher.

\section{Regiment.}

\section{Collonell Sir Thomas Glen- $\mid$ Liev. Collonell Vaughan.5s ham. ${ }^{5-}$ Sergeant Major Wagftaffe. .56}

${ }^{52}$ Theobald Taffe, fon and heir of John, firt Vifcount Taffe, in the Peerage of Ireland.

${ }^{3} 3$ Second fon of Henry, fifth Earl of Huntingdon, who died, 14th November, 1643 , by Elizabeth, third daughter of Ferdinando Stanley, Earl of Derby. Created Baron of Loughborough, co. Leicefter, $23^{\text {rd }}$ October, 1643. Died without iffue, 1666 .

${ }^{54} \mathrm{Sir}$ Thomas Glenham was fucceffively Governor of York (furrendered, July 16, 1644), Carlifle (furrendered, June 28, 1645), and Oxford (furrendered, June 20, 1646). Confined by the Parliament in the Fleet prifon. Died in Holland before the Reftoration.

"Tho. Glenham cui caftra Carleolente

\& Eboracenfe Monumentum funt

\& Oxonium Epitaphium."-Lloyd's Memoires, p. 552.

His brother, Henry Glenham, fometime Dean of Briftol, was Bifhop of St. Afaph, 1667-1670.

${ }^{35}$ It is probable that Sir George Vaughan of Penbrey is the perfon here 
Captaine Long.

Captaine Coney. ${ }^{57}$

Captaine Starkeley.
Captaine Smart.

Captaine Jackfon.

\section{Regiment.}

-Collonell, Sir Francis Wortley. ${ }^{53}$ Lievtenant Collonell Ruffell. Serjeant Major Waller.
Captaine Tukes. Captaine Stafford. Captaine Shelton. ${ }^{59}$

\section{Regiment.}

Lord Grandifon, Lievtenant Generall. ${ }^{60}$
Liev. Collonell John Digby. ${ }^{61}$ Serjeant Major Willoughby.

indicated. He was feverely, but not fatally, wounded by a blow on the head with a pole-axe at Lanfdowne fight, July 5, 1643. Another perfon of this name, Sir William Vaughan, fought for the King in South Wales, Chefhire, and Shrophire. He was killed near Dublin, Aug. 22, 1649.

${ }^{56}$ Sir Jofeph Wagftaffe was wounded when the Royalifts took Lichfield, 1643. Engaged in the Weftern rifing, 1655, and was with difficulty diffuaded by his companions from hanging the Parliamentary Judges and the High Sheriff of the county who had fallen into their hands at Salifbury. After the ruin of the enterprife he efcaped abroad.-CLARENDON's Hiffory, p. 82 5 .

${ }^{57}$ Sutton Coney was fon and heir of Sir William Coney, Knight, a Commiffioner of Array for Lincolnhire. I am not certain that he is the perfon here indicated.

${ }^{58}$ Sir Francis Wortley was fon of Sir Richard Wortley, Knight, of Wortley, co. York. Educated at Magdalen College, Oxford, created a Baronet, June 29, 161 I. In the early part of the Civil War he fortified Wortley Hall for the King. He was taken prifoner at Walton Hall near Wakefield, the feat of the Knightly family of Waterton, on the $3_{\text {rd }}$ of June, 1644 . Authorities differ as to the time and place of his death ; it is, however, certain that he departed to his reft before the monarchy was reftored. He was the author of feveral books, a lift of which may be feen in Wood's Athene Oxon. His arms were argent, on a bend

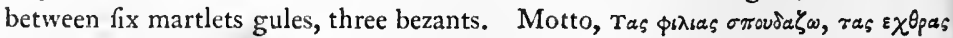
xara $\phi$ powew.-HUNTER's Deanery of Doncafter, vol. ii. pp. 308-326.

${ }^{59}$ Serjeant Major Sheldon was mortally wounded at Lanfdowne fight, July 5, 1643 , by the explofion of an ammunition waggon.-CLARENDON'S Hift. p.404.

${ }^{60}$ William Villiers, Vifcount Grandifon in the Peerage of Ireland, fon and heir of Sir Edward Villiers. Prefident of Munfter ; brother to George Villiers, 
Captaine Tempeft. ${ }^{62}$

Captaine Morgan.

Captaine Crane.

Captaine Mufgrave.
Captaine Badger.

Captaine Hillyard. ${ }^{63}$

Captaine Muggridge.

\section{Regiment.}

\section{Collonell Endimion Porter. ${ }^{64}$}

Lievtenant Collonell Vavajor. ${ }^{65}$

Duke of Buckingham, by his wife Barbara, daughter of Sir John St. John of Tregofe, co. Wilts, and niece to Oliver St. John, created Vifcount Grandifon, with limitation of the title to his niece's pofterity. Lord Grandifon was wounded at the fiege of Briftol, July 26, x643, and died of his wounds at Oxford the 29 th of September following. He lies buried under a Ptately monument in Chrift Church Cathedral, which his daughter, Barbara Villiers, afterwards Duchefs of Cleveland, erected to his memory.

61 Sir John Digby, a younger fon of the Earl of Briftol (note 39). Raifed a troop of horfe for the King; commanded the cavalry at the battle of Stratton, May 16,1643 . He was one of the fix perfons excepted from mercy at the furrender of Pontefract Caftle, but fucceeded in eluding his enemies by lying hid within its precincts for about ten days, and then making his efcape unobferved. Sir John Digby furvived the Reftoration.-CLARENDON's Hifl. pp. 397, 42 5, 670. SURTEES' Mifcellany, vol. i. pp. 2, 93.

${ }^{62}$ John Tempert, ninth fon of Sir Stephen Tempeft of . . . . co. York. Slain at the taking of Drogheda, Aug. 14, 1649. He was a Roman Catholic. Arms, argent, a bend between fix martlets, fable.-DugdalE's Herald's Vijit. rorks. $1665-6$, p. 360.

${ }^{63}$ Robert Hillyard of Beverley and of Wineftead, co. York, fon of Sir Chriftopher Hillyard, Knight. Created a Baronet after the Reftoration. Arms, azure, three mulletts, or.-Poulson's Holderne/s, vol. ii. p. 473 .

${ }^{64}$ Gentleman of the bedchamber to Charles I. One of thofe who accompanied him, when Prince of Wales, to Spain. Died abroad before the Reftoration. ${ }_{65}$ Three brothers of the family of Vavafour of Hafelwood, co. York, were in the King's fervice. They are thus noticed in Dugdale's Pedigree (Herald's Vifit. co. York, x66 5-6, p. 345):-

"I. Sir Walter Vavafour of Hafelwood, Bart. Colonell of a Regiment of Horfe under the right honorable Willm Marqueffe of Newcaftle, for the fervice of $\mathrm{K}$. Charles the firft in the times of the late Rebellion. FEt. 53 ann. 13 Aug. $\mathbf{6} 666$.

"II. Willm Vavafour a Major in that Reginnt of Horfe under his brother. 
Sergeant Major Stanhope. ${ }^{66}$ Captaine Williams. Captaine Berry. Captaine Tijdale.
Captaine White. Captaine Owen. ${ }^{67}$ Captaine Beefley. Captaine Thírlow.

\section{REGIMENT.}

Colonell Afhburnham. ${ }^{63}$

Lievtenant Bruerton.

- Sergeant Major Carey. ${ }^{69}$

Captaine Huet.

Captaine Fowler.
Captaine Ridgley. Captaine Wafher. Captaine Bowen. Captaine Ballard. ${ }^{70}$ Captaine Weeks.

" III. Thomas Vavafour flayne in $\mathrm{y}^{\mathrm{e}}$ Battaile of Marfon Moore neer Yorke, fighting on the behalfe of $\mathrm{K}$. Ch. the firt, $\mathrm{a}^{0} \times 644 . "$

Philip Stanhope, firft Baron Stanhope of Shelford, and Earl of Chefterfield, had two fons in the Royal Army.

Ferdinando, his fourth fon, M.P. for Tamworth in the Parliament of 1640 , D.C.L. Oxford, 1642 . Slain at Bridgford, co. Notts, 1643 . This is probably the perfon here indicated.

Philip, fifth fon, loft his life at his father's feat at Shelford when it was taken by ftorm, O\&. 27,1645 .

${ }^{67} \mathrm{Sir}$ John Owen of Klinenney, co. Caernarvon. Vice-Admiral of Nortt Wales; wounded at the taking of Briftol, July 26, 1643. Tried by the High Court of Juftice with the Duke of Hamilton and Lord Capel, fentenced to death, but fubfequently pardoned.

${ }_{68}$ Wiliiam Afhburnham, fon of Sir John Amburnham of Afhburnham, co. Effex, and brother to John Ahburnham who was one of the Royal Commiffioners for the treaty of Uxbridge. He was a member of the Parliament of 1640. Governor of Weymouth, which he furrendered, and occupied Portland Caftle, June 14, 1644. After the Reftoration made Cofferer to Charles II. Died without iffue, 1679 .

${ }^{69}$ Sir Henry Carey of Cockerington, co. Devon, Knight.

70 "Sir Thomas Middleton, and Colonel Mitton, took a garrifon of the Kings near Mountgomery, and in it, Colonell Ballard the governor."-W HITELock, Dec. 1644. Slain at the fiege of Taunton, co. Somerfet.-MicroChronicon, $\mathrm{x} 647$. 
9 Regiment.

Colonell Bellajis. ${ }^{11}$

Lievtenant Collonell Murrey. Serjeant Major Pope.

Captaine Holloway.

Captaine Legge. ${ }^{72}$

Captaine Withers.

Captaine Hodges.

Captaine Homer.

Captaine Metoo.
Captaine Barret.

Commifary Wilmot, MufterMafter Generall, one Troop of Horfe. ${ }^{73}$

Secretary Nicholas, Secretary of State, one Troope of Horfe. Mafter Sidenham, Knight Marfhall, one Troope of Horfe.

Io Regiment.

\section{Vifcount Killmurrey, Sergeant $\mid$ Liev. Colonell Sir Faithfull Major Generall. ${ }^{74}$ Forte $\int$ cue. $^{75}$}

"John Belafyfe, fecond fon of Thomas, firt Vifcount Falconberg (fee note 28). Created Baron Belafyfe of Worlaby, co. Lincoln, Jan. 27, 1645. Wounded at the taking of Briftol, 1643. Defeated and taken prifoner at Selby, co. York, April 11, 1644. Governor of Newark, Oct. 20, 1645, which he furrendered by command of the King, May, 1646 . Imprifoned upon fufpicion of defigning new troubles, April 16, 1651. Liberated, Nov. 2, 1659. Died, I689. ${ }^{72}$ William Legge, wounded at Lichfield, April 8, 1643 . Imprifoned while Governor of Oxford, Sept. 17, 1645, owing to his friendhip with Prince Rupert, whofe commiffion the King had taken from him.

${ }^{73}$ Henry Wilmot, fecond Baron Wilmot in Ireland. Created Baron Wilmot of Adderbury, co. Oxford, June 29, 1643, and Earl of Rochefter, Dec. 13, 1652. He liad ferved in the Low Country Wars before the beginning of the domeftic troubles. Appointed Commiffary General of the Horfe in the expedition into Scotland. Taken prifoner by the Scotch at the battle of Newburn, Aug. 28, 164.0. Reftored by the Commifioners who met at the treaty of Ripon, September, 1640. Wounded at the battle near Worcefter, Sept. 23, 1642. Defeated Sir William Waller at Roundway Down, July 5, 1643. Arrefted by the King for high treafon, 1644. Accompanied Charles II. to Scotland, 1650. Died, 1659 .

${ }^{74}$ Robert Needliam of Shenton, co. Salop, fecond Vifcount Needham in the Peerage of Ireland. Died ${ }_{16} 53$, and was fucceeded, as third Vifcount, by his fon Robert, who joined in the rifing in favour of Charles II, Auguft, 1659. 
Sergeant Major Pollard. ${ }^{70}$

Captaine Bulhead.

Captaine Prowfe.

Captaine Thomas.
Captaine Colesfoote.

Captaine Atkinfon.

Captaine Bateman.

Captaine Denby.

\section{Regiment.}

Sir Lewis Dives, Colonell. ${ }^{77}$

- Liev. Colonel Lucy. Sergeant Major Withrington. ${ }^{78}$ Captaine Browne.
Captaine Thomas Furbufh.

Captaine Ley.

Captaine Johnfon.

Captaine Sling $\int b y \cdot{ }^{79}$.

In " a lift of the prifoners of Quality now fecured in Chefter," publifhed in the Mercurius Politicus, Sept. 1-8, 1659, occur "Lord Kilmorey" and "Mr. Thomas Nedham, Brother to Lord Kilmorey."

${ }^{75}$ Sir Faithful Fortefcue was colonel of the third troop of horfe raifed for the expedition into Ireland, $\mathbf{1 6 4 2}$. He was with his troop draughted into the Parliamentary Army under the command of the Earl of Efrex. At Edge Hill battle, Sir Faithful Fortefcue with his whole troop left the Parliamentary Army " and prefented himfelf and his troop to Prince Rupert .... The fudden and unexpected revolt of Sir Faithful Fortefcue with a whole troop .... had not fo good fortune as they deferved; for by the negligence of not throwing away their orange tawney fcarfs, which they all wore as the Earl of Effex's colours, and being immediately engaged in the charge, many of them, not fewer than feventeen or eighteen, were fuddenly killed by thofe to whom they had joined themfelves."-CLARENDON's Rebellion, pp. 308, 309.

Arms, azure, a bend engrailed, argent, cotized, or.

${ }^{76}$ Pollard, Sir Hugh, flain at Dartmouth, Jan. 18, 1646.

7 Wounded at Worcefter, Sept. 23, 1642. Made prifoner at the taking of Sherbourne Caftle, of which he was governor, Aug. 15, 1645. Efcaped from cuftody, Jan. 30, x649.

${ }^{78}$ Sir William Widdrington, firft Baronet. Created Baron Widdrington of Blankney, co. Lincoln, Nov. 10, 1643. "He was one of the firt who raifed both horfe and foot at his own charge and ferved eminently with them under the Earl of Newcaftle."-Clarendon's Hift. p. 763.

Killud at the battle of Wigan, Lancarhire, Aug. 27, 1651 .

${ }^{79}$ Sir Henry Slingfby, Bart. of Scriven, co. York. A member of the Parriament of 1640 . Defeated by Sir Hugh Cholmley at Guilborough, Jan, 16, 1643. Taken prifoner in Cornwall, Jan, 1650. Imprifoned in Pendennis and Exeter Caftles. Tried by a Court of High Commiffion. Beheaded on Tower 
12 Regiment.

Colonell Sir Charles Lucas. ${ }^{80}$

Liev. Colonell Stanley.

Sergeant Major Kelley.

Captaine Hodges.
Captaine Ford.

Captaine Burley.

Captaine Strangewayes.

Captaine Whiteaway.

\section{I3 Regiment.}

Colonell Sir George Gotherick. Lievtenant Colonell Wafhington.

Sergeant Major Powell.

Captaine Ifaack.
Captaine Johnfon.

Captaine Lever.

Captaine Burrowes.

Captaine Sutton.

\section{I4 Regiment.}

Colonell Ofborne. ${ }^{81}$

Liev. Colonell Savage.
Sergeant Major Oneale. ${ }^{82}$ Captaine Forfter.

Hill, June 8,1658 . An interefting diary, written by Sir Henry Slingfby, has been preferved and twice printed. The beft edition is that edited by D.Parfons, M.A. 8 vo. $183_{3} 6$.

${ }^{80}$ Sir Charles Lucas, elder brother (born of the fame parents, but before wedlock) of John, firt Baron Lucas of Shenfield, co. Effex, and next heir of his brother's barony and eftates.-Nicholas's Hiftoric Peerage, 1857, p. 301.

Tried by Court Martial and thot after the fiege of Colchefter, Aug. 28, 1648 . "He was very brave in his perfon, and in a day of battle a gallant man to look upon and follow ; but at all other times and places of a nature not to be lived with, of an ill underftanding, of a rough and proud nature, which made him during the time of their being in Colchefter more intollerable than the fiege."-CLARENDON's Hift. pp. 664, 5.

${ }^{81}$ Edward Orborne of Kiveton, co. Notts, Knight. Created a baronet, July 13, 1620. Vice-Prefident of the North of England, 1629. Father of Thomas Oborne, firft Duke of Leeds.-THORESBY's Ducatus Leodien/is, p. 2.

${ }^{82}$ Daniel O'Neill was active in opporition to the Earl of Strafford. Committed to the Tower by the Parliament, from whence he efcaped in women's clothing, and fled to the Low Countries. He returned and joined the 
- Captaine Vaux.

Captaine Holyday.

Captaine Huffey.

Prince Robert, Generall of the Horfe.

Sir'Thomas Byron, ${ }^{83}$ chiefe Commander of the Princes Troopee containing about 500 Horfe.

The Earle of Briftoll, two Troops.

The Earle of Crawford, ${ }^{84}$ three Troops.

The Lord Digby, ${ }^{85}$ two Troops. Lord Capell, two Troops. The Lord Willoughby, two Troops.

I have omitted the Earle of Cumberland his Horfe and foot, The Marqueffe Hertfords Horfe and foot The Earle of Darbies Horfe and foot, which is at the leaft 16000 .

None of which have been as yet with His Majeftie, fo that in all parts His Majefties Army of Horfe and Foot is Juppofed to be 40000 Souldiers.

King at the breaking out of the Civil War. After the Reftoration, Charles II. let him the poit office to farm. Died, r664. He was the only Protertant of his family. "It is more to be called an Oneal than an Emperor in Ireland." -Lloyd's Memoires, p. 665.

83 Sir Thomas Byron, brother to John, firf Lord Byron. Dangerouny wounded at the battle of Hopton Heath, March 19, I643.

84 Ludovick Lindfay, fifteenth Earl of Crawfurd in the peerage of Scotland. Taken prifoner at the battle of Worceiter, Sept. 3, I6 5 I.

${ }^{83}$ George Digby, fon and heir of John Digby, firft Earl of Briftol. Summoned to Parliament in his father's barony of Digby, June 9, r641. K. G. Died, 1676.

${ }^{86}$ Sir John Byron. Created Lord Byron of Rochdale, co. Lancashire, O\&t. 24, 1643 . Died, 1652 . 


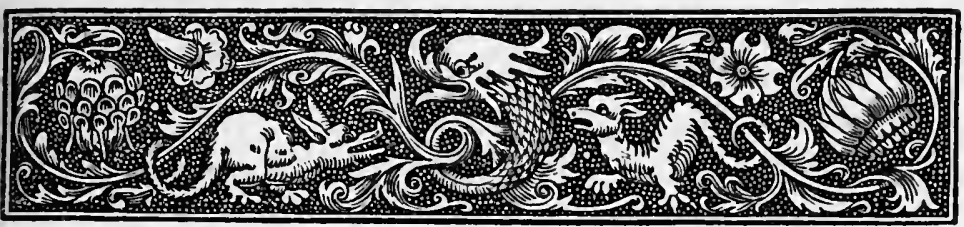

\title{
THE LIST OF THE ARMIE.*
}

\author{
Officers generall of the Field.
}

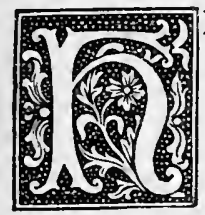

IS Excellency Robert Earle of Efex, Captaine Generall..$^{87}$

Philip Skippon Serjeant "Major Generall and Pre 1 ident of the Councell of Warre. ${ }^{88}$

Captaine James Seigneur Provoft Marfhall Generall. Thomas Richardfon Carriage Mafter Generall.

* This lift of the Parliamentary Army exifts in a feparate form as a fmall 4 to. of twenty pages. It varies from the document here reprinted but very flightly. As this pamphlet is of extreme rarity, I give the title-page in full.

"The Lift of the Army Raifed under the command of his Excellency ROBERT Earle of Effex and Ewe, Vifcount Hereford, Lord Ferrers of Chartley Bourchrir and Lovaine: Appointed Captaine General of the Army, Imployed for the defence of the Proteftant Religion, the fafety of his Majefties Perfon and the Parliament, the prefervation of the Lawes, Liberties and Peace of the Kingdom and protection of his Majefties Subjects from Violence and oppreffion.

"With the names of the feverall Officers belonging to the Army.

"London Printed for John Partredge, I642."

${ }^{67}$ Robert Devereux, fon and heir of Robert Devereux, fecond Earl of Effex, who was beheaded for High Treafon, I601. Reftored in blood and honours, July 12, 1603. One of the twenty-feven peers who tried Mervin Tuchett, Lord Audley, Earl of Caftlehaven, I $_{3} \mathrm{I}$. Appointed by the Parliament General of the forces, July 12, 1642. Commanded at the battle before Worcefter, Sept. 23, 1642; Edge Hill, O\&t. 23, 1642; the taking of Reading, April 18, 1643; 


\section{Officers of the Lord Generalls 'Train.}

- Sir Gilbert Gerrard Knight, Trea furer at Warres.

Lionell Copley Efquire, Mufter-Mafter Generall. ${ }^{89}$

Doctour Ifaak Dorifla, Advocate of the Army. ${ }^{90}$

Henry Parker Efquire, Secretary of the Army.

Robert Chambers, Auditor of the Army.

Newbury (firft battle), Sept. 19, 1643; Taunton Deane, June 22, 1644. Died, Sept. 14, 1646. Buried in St. John Baptift's Chapel, Weftminfter Abbey, in a grave where Bohun, Abbot of Weftminfter, had been buried (temp. Ric. II.), Oet. 19, r646.-Devereux, Lives of the Devereux, ii. 362-470. Oldmixon's Hiftory of the Stuarts, p. 315 .

${ }^{88}$ Philip Skippon is faid to have been a man of humble birth; he had ferved in Holland, where he had raifed himfelf from the rank of a common foldier. He was fubfequently one of the Protector Oliver's Council of State. He became poffeffed of Hirham, in Suffex, where he was fucceeded by his fon, Philip Skippon, F.R.S. Arms, gules; five annulets, or.-CLaRENDON's Hift.p. 152. PREsTwick's Rejpublica, p. 96 .

In the Lift of the Army Raifed under the command of his Excellency Robert Earle of Eflex, $\sigma^{\circ} c$. London Printed for Fohn Partredge, $164_{2}$, Sir John Merrick is given as filling the place here occupied by Philip Skippon. Clarendon fays that Skippon was made Serjeant Major General of the army in the room of Sir John Merrick by the authority of Parliament, " without the chearful concurrence of the Earl of Effex, though Sir John Merrick who had executed that place by his Lordfhip's choice from the beginning was preferred to be General of the Ordnance."-P. 382.

${ }^{89}$ Lionel Copley, fecond fon of William Copley of Wadworth, co. York. Died in London, Dec. 7, 1675. Buried at Wadworth. More than one member of this family fought on the fide of the Parliament. Arms, argent, a crofs moline fable. The mottoes borne by the Copleys on their banners were, "For Reformation," and, "Nay, but as a captain of the Hoft of the Lord am I come."-HunteR's South Yorkfhire, i. 25 r.

${ }^{90}$ Ifaac Doreflaus, Doreflaer, Doriflaer, or Doorlaer, for the name is fpelt thus variouly, was fon of Abraham Dorellaer; the date and place of his birth are not known. The accompanying table embodies fuch facts as are recorded of his family. 


\section{Officers Generall of the Horse.}

\section{William Earle of Bedford, Lord Generall. ${ }^{91}$ \\ Sir William Belfoore Knight,"'Lievtenant Generall. ${ }^{92}$}

Abraham Doreflaer, a minifter of the Dutch Reformed Church at Oude, $\bar{T}$ Niedorp, in 1602 ; Eukhuizen in 1605 , where he died, March 19, 1655. Author of "A new tranflation of HOLY WRIT with Explanations and notes." Amfterdam, 1614, folio. A "Treatife concerning the differences between the tenets of the Reformed and Anabaptift perfuafions, \&c."

1. Samuel Doreflaer, minifter at Werverfhoof, $16{ }_{3} 8$; at Brock, in Waterland, 1645 ; at Delft, 1648 , where he died, I6 53 .
2. Ifaac Doreflaer, $=$ minifter at Henibrock, 1627 ; at Enkuizen, 1628, where he died, 1652 .
3. David Doreflaer, minifter of the Dutch colonilts in Brazil. Returned to Holland and became minifter at Hobrede and Ofthniazen, I644; Hultezen, I649; Tholen, I650; Zierikzen, 1654 . Died, 1671 .

Ifaac Doriflaus.

Ifaac Doriflaus was.a friend of Sir Henry Mildmay, and the firft Lord Brooke. Through thejinfluence of the latter he was appointed to read a hiftorical lecture in Cambridge ; but was foon filenced on account of his maintaining anti-monarchical principles. His great knowledge of Civil Law caufed his nomination to the office of Judge Advocate of the Army. For the fame reafon he was thortly afterwards made one of the Judges of the Court of Admiralty. He made himfelf efpecially hateful to the Royalifts by affifting to prepare the charge of High Treafon againft Charles I. In the beginning of May, 1649 , he failed for Holland as Envoy from the Englifh Parliament to the Hague; he had only fpent a very fhort time there when, on the 12 th, or, according to others, the $15^{\text {th }}$ of May, as he was taking his fupper at the Witte $Z$ waan (White Swan) Inn, fome five or fix men in mafks entered the houfe, blew out the lights in the paffage, and rufhed into the public room, where he, in company with eleven other guefts, was fitting. Two of the confpirators imınediately made a murderous attack on a Dutch gentleman named Grijp van Valkeniteyn, fuppofing him to be the Englifh Envoy. Finding out their miftake, however, they fet upon Doreflaus, and flew him with many wounds, exclaiming as they did the deed, "Thus dies one of the King's Judges." The leader of this execrable gang was Col. Walter Whitford, fon of Walter Whitford, D.D., of Monkland, in Scot- 
John Dulbier, Quarter-Mafter Generall. ${ }^{93}$

Sir Edward Dodfworth, Commifary for the Horje.

John Ward, Commifary for the Provifions.

John Baldwine, Provoft Marfhall Generall.

\section{A List of the Train of Artillery.}

John Earle of Peterborough, Generall of the Ordnance. ${ }^{94}$

Philibert Emanuel de Boyes, Lievtenant Generall of the Ordnance. Nicholas Cooke, an Afiftant to the Lievtenant of the Ordnance. Alexander Forboys, a Surveyor or Comptroller. John Lyon, an Engineer.

Six other Engineers Adjiftants.

George Vernon $\}$ two Commiffaries of the Ordnance, Materialls, John Phipps $\}$ and Ammunition.

A Commiffary to diftribute Victualls.

Captaine Peter Cannon, a Purveyor Generall, both for Munition and all other neceffaries belonging to the Ordnance.

land. He received a penfion for this "generous action" (Wood) after the Reftoration. The Englifh Parliament gave their faithful fervant a magnificent funeral in Weftminfter Abbey, June 14, 1649; but after the Reftoration thofe in power difturbed the body. His duft now refts with that of Admiral Blake, and others fuch as he, in a pit in St. Margaret's Churchyard.-JOHN LODEN GollPRIED's Kronyck, iv. 454. VAN DER DA, Biographifch Woodenbock, in voc. There is a portrait of Ifaac Doreflaus by R. Vinkeles.

91 William Ruffell, fifth Earl of Bedford, fucceeded his father, 1641 . Created Duke of Bedford, May x 1, 1694. Died, 1700 . Commanded the body of referve at Edge Hill, O\&t. 23, 1642. Left the Parliamentary fervice and joined the King at Oxford.

${ }^{92}$ Sir William Balfore, Lieutenant of the Tower. Difmiffed from that office, 1640. Commanded the Horfe at Edge Hill, Oct. 23, 1642 .

${ }^{93}$ John Dalbier, or Dalbeer, a Dutchman " of name and reputation, and good experience in War," was left out of the newly formed army, and being difcontented, ;oined the rifing of the Earl of Holland. Killed in an inn at St. Neots, co. Huntingdon, July 5,1648 .

94 Henry Mordaunt, fecond Earl of Peterborough, fucceeded to the earldom on the death of his father, June 18,1642 . Died, June 19,1697 . Buried at Turvey, co. Bed. 
Eighteen Gentlemen of the Ordnance.

I Tho. Holyman.

2 Robert Barbar.

3 Patrick Strelley.

4 Adward Waje.

5 Anthony Heyford.

6 Robert Bower.

7 Henry Edfon.

8 James Francklin. ${ }^{95}$

9 Richard Honey.
Io Jofhua Sing.

I George Ranfom.

12. Samuel Barry.

I3 Daniell Barwick.

I4 Tho. Rawfon.

I5 Tho. Sippence.

I6 Tho. Croffe. ${ }^{96}$

17 Tho. Ayres.

I8 William Hickfon.

John Fowke, a Mafter of the Carriages, or Waggon Mafter for the Artillery.

Will. Crawley, a principall Conductor of the Train of Artillery for the Draught-Hor $\int e s$ and Ammunition.

Edward Weft, a Commiffary of the Train of Artillery for the draught-Horfes.

George Wentworth, a Quarter-Mafter of the Traine of Artillery.

Edward Frod]ham

Henry Roe

John Dungan

three Captaines to 600 Pyoners.

Gerard Wright

$\left.\begin{array}{l}\text { Benjamin Hodfon } \\ \text { Tho. Williams }\end{array}\right\}$ three Lievtenants to 600 Pioneers.

Lancelet Honiburne, Mafter Gunner.

Chriftopher Troughton, Provoft Marfhall of the Artillery.

Edward Okely, a Battery-Mafter.

25 Slain at Exeter.-SPRIGG, p. 330.

${ }_{96}$ Slain at the fiege of Sherborne Caftle, Aug. 15, 1645.-Micro-Chronicon, 1647.

97 Slain at Ofweftree, co. Salop, June $15,1644$. 
Joakim Hane, Fire-worker and Petardier.

William Roberts, Fire-rvorker and Petardier.

Harman Browning, a Bridge-Mafter for the Traine of Artillery. Jo. Herdine, an Afjiftant unto him.

Lievtenant Generall De Boys, Captaine of roo Fire-locks. Rich. Price, Lievtenant to Captaine de Boys.

\section{THE LIST OF THE SEVERALL REGIMEN'TS OF FOOT AND HORSE.}

\section{His Excellencies Regiment.}

Captaines.

Colonell his Excellency.

Liev. Col. W. Davies. ${ }^{93}$

Sir M. Jo. Bamfield.

Sir Antho. St. John.

Chr. Mathias.

Jo. Skrimpfhiere.

Tho. Skinner.

Roger Bettridge.

Tho. Ward.

Edw. Leventhorp.

\section{Lievtenants.}

John Rainsford. ${ }^{99}$

Fulk Mujket.

Hugh Juftice.

Wal. Reed.

Geo. Clark.

Alex. Edwards.

Jo. Cracroft.

Tho. Lanford.

Hen. Stevens.

98 At Newbury, firft battle, " on the parliament's part were flain about 500, colonel Tucker and the Lievtenant colonel of Effex's Regiment."-WhiTELOCK, p. 215.

${ }^{99}$ Draughted out of the Earl of Effex's Regiment into that of Sir Thomas Fairfax, March, 1644 . Killed by Cavaliers from Pontefract Caftle in an attempt to take him prifoner at Doncafter, Oet. 29, I648. Buried at Wapping, Nov. 14. Arms, chequered or, and azuie in fefs, a Moor's head in profile, bearded proper, wreathed argent.-HUNTER's Deanery of Doncafter, vol, i. p. 26 . 
Enfignes.

John Lloyd.

Jenkin Song.

Edw. Cockram. ${ }^{100}$
Will. Bowen.'

Jo. Johnfon.

Tho. Haftings.

Andr. Ward.

Hugh Harding.
Sir Philip Stapleton ${ }^{2}$ Captain of 100 Curafliers for his Excellencies Guard.

Adam Baynard Lievtenant. Paul Grefham Quarter-majter.
Captain Nathaniel Draper Captaine to the General's Troop of 50 Carbines.

John Strelley Cornet.

Abraham Carter Quarter Mafter.

FIRE LOCKS.

\section{Captains.}

Robert Turner.

Ambrofe Tindall.

Nicholas Devereux.

\section{Pbyfitian to the Traine and Perfor.}

Doctor John Saint John. ${ }^{3}$
Chirurgion to the Traine and Perfon.

Laur. Lowe.

Chirurgion to the Regiment.

William Parkes.

Lievtenants.

V Jeus Martery.

${ }^{100}$ Lieutenant Cockeram, flain before Scarborough, May, 1645.

1 Lieutenant Colonel in Rainßborough's troop, 1647.

${ }^{2}$ Sir Philip Stapleton inherited " but a moderate eftate in Yorkfhire, and, according to the cuftom of that country, had fpent his time in thofe delights which horfes and dogs adminifter." A member of the long Parliament; joined in the profecution of Strafford; oppofed the felf-denying ordinance, 1644 . Withdrew beyond fea, and died at Calais as foon as he landed. "Was denied burial upon imagination that he had died of the plague."-CLARENDON, Pp. $119,618$.

${ }^{3}$ The perfonal attendant of the Earl of Effex.-Letters of the Devereux, ii. p. 444 . 
Nich. Halford.

Tho. Lawrence.

Carriage Mafter.

William Wren.
Chaplain.

Stev. Marfhall.

Chaplain for the Regiment of

$$
\text { Horje. }
$$

Doctor Burges. ${ }^{4}$

\section{Sir John Merricks Regiment.}

- Col. Sir Joh. Merrick. ${ }^{5}$ L. C. Vincent Kilmady. Ser. M. Will Herbert.

Captains.

...... Tyer.

....... Lower.

Fran. Merrick.

Tho. Lawherne. ${ }^{6}$

John Lloyd.
John Edwards. John Baily.

Provof Marßhall.

Iohn Theme.

Chaplain.

...... Tucker.

Chirurgion.

John Woodward.

${ }^{4}$ Cornelius Burgefs, of the family of Burgefs of Batcombe, co. Somerfet. Entered the Univerfity of Oxford, r6ri. D.D. 1627 . One of the moit popular preachers during the Civil War. Loft his property at the Reftoration. Died in extreme want at Watford. Buried in Watford Church, June 9, 1665.

"Wee'l break the windows which the whore

Of Babylon hath painted,

And when the Popinh faints are doun,

Then Burgefs thall be fainted;

There's neither croffe nor crucifix

Shall ftand for men to fee,

Rome's trafh and trumpery thall go down,

And hey then up go we."

Rump Songs, If edit. p. I5.

5 See note 88.

- Thomas Laugherne, or Langhorn, a gentleman of South Wales, had ferved the Earl of Effex as a page in the Low Countries. Deferted the Parliament in company with Powell and Poyer. He was taken prifoner by Oliver Cromwell in Pembroke Caftle, July II, 1648. 
The Earle of Peterboroughs Regiment.

Col. Jo. E. of Peterborow.

L. C. Sir faithf. Fortefcue.

S. M. Francis Fairfax.

\section{Captains.}

Sir Edw. Payton.

Phil. Dutton.

Bevill Prideaux.

Robert Knightley.

Io. Butler.

Hen. Lovell.

Geo. Blunt.

\section{Lievtenants.}

Geo. Rowse.

Rich. Orfice.

Jo. Rice.

Will. Thorp.
Hen. Caje.

Ornall Fountain.

Tho. Treeft.

Jo. Balftone.

Geo. Hartridge.

Jam. Grimes.

Enfigns.

...... Goldjborow.

John Apew.

Alex. Thory.

Jo. Bridges.

Jam. Harrifon.

Bevill Cruttenden.

Rich. Lidcoat.

Tho. Laham.

Jo. Pew.

Cha. Harrow.

The Earle of Stamfords Regiment.

Col. Hen. E. of Stamford.?

Liev. Col. Edw. Mafie. ${ }^{8}$

Ser. M. Conft, Ferrer.

\section{Captains.}

Tho. Savill.

7 Henry Grey, fecond Baron Gray of Groby. Created Earl of Stamford, co. Lincoln, March 26, 1628. Died, Aug. 21, 1673. His fon, Thomas Grey, commonly called Lord Grey of Groby, died during his father's life, leaving male iffue.

${ }^{8}$ Edward Maffey is faid to have offered his fervices to King Charles I. before he was retained by the Parliament. Governor of Gloucefter, which he fuccefsfully defended againft the Royal forces. Deprived of his commiffion by the felf-denying ordinance, 1644. Joined King Charles II ; was taken prifoner after the battle of Worcefter, Sept. 3, 1651, but efcaped abroad. 
Edw. Gray.

Charles Blunt.

Peter Crípe.

Ifaack Dobfon.

Arnold Cojbie.

Jo. Bird.

\section{2uarter Mafter.}

Ferdinando Gray.

Carriage Mafter.

Rich. Phillips.

\section{Lievtenants.}

John Clifton.

James Harcus.

William Hewet.

William White.

James Bock.

Robert Hampfon.
Jo. Hemens.

Nath. Tapper.

Robert Mallery.

Hen. Cantrell.

Chirurgion.

Jo. Rice.

Enfigns.

John Chambers.

John Starkey.

Tho. Griffin.

William Pincock.

James Gray.

Hen. Collingwood.

Tho. Barnes.

James Baker.

Laur. Clifton.

Provof Marßhall.

Robert Powell.

The Lord Sayes Regiment.

Col. William Lord Say. ${ }^{9}$

L. C. . . . Hutchinfon.

Ser. M. Ja. Atchajon.

Captains.

Geo. Marrow.

Chrifto. Burgh.

Jam. Temple.
Walter Lloyd.

Morgan Tinne.

Robert Blowe.

Buffy Baffet.

Quarter Mafter.

Hum. Dix.

2 William Fienes, eighth Baron Say and Sele. Created Vifcount of Say and of Sele, July 7, 1624. Died, 1662. 
Lievtenants.

Iohn Rainsford.

Luke Weekings.

Jam. Hannam.

...... Hoare.

...... Langford.

Tho. Haynes.

Wil. Howard.

Jon. Newcomin.

Edw. Cawardine.
Enfigns.

Iohn Butcherfield.

Jofeph Farnes.

Io. Kelly.

...... Corby.

Ben. Lee.

Tho Colledge.

..... Gittings.

Tho. Sweeper.

Prue. Prideaux.

The LoRd Whartons Regiment.

\section{Phil. L. Wharton. ${ }^{10}$} Liev. Col. Jer. Horton. Ser. Ma. Owen Parry.

\section{Captains.}

Robert Long.

Henry Carew.

Jude Leigh.

Henry Skipwith.

Chr. Baily.

...... Gibbons.

Elias Struce.

\section{Provof Marhall.}

George Higham.

\section{Lievtenants.}

Ch. Holcroft.
Fr. Fit fhues.

Edw. Browne.

Tho. Albany.

Wil. Browne.

Will. Bridges.

George Ufher.

William Emerfon.

Anthony Mafham.

Ifaac Turney.

Chirurgion.

Jo. Broughton.

Enfigns.

...... Blake.

Tho. Radford.

Robert Hughes.

Roger Moore.

10 Philip Wharton, fourth Baron Wharton. Succeeded to the peerage on the death of his grandfather, Philip Wharton, third Baron, 1625. Died, 1696. 
Wil. Heydon.

Edw. Horton.

Jo. Garret.
Jer. Gardiner. Rich. Bland.

Edw. Horton.

The Lord Rochfords Regiment.

Col. Lord Rochford."1

Liev. C. Ed. Aldrich.

Ser. Ma. Tho. Leighton.

\section{Captains.}

Tho. Drake.

George Walfh.

Philip Ballard.

Benjamin Hooke.

Fran. Hudjon.

Jasper Brand.

Geo. Willoughby.

$$
\text { Quarter-Mafter. }
$$

Miles Dobfon.

\section{Chaplain.}

Io. Page.

\section{Lievtenants.}

Io. Norhhip

William Shawe.

Edw. Deering. Walter Bradley.
Ralph Carter.

Edw. Melfon.

Jo. Sheppard.

Matth. Stoaker.

Humphry Dimock.

Miles Afhton. -

\section{Provof Marhall.}

Io. Burbeck.

Enfignes.

Henry Newdigate. Mount Sanders. Jeffery Lloyd. Peter Blewin.

Edw. Lovell.

George Burrell.

William Williams.

Hen. Smith.

Jo. Bramfton.

Carriage Mafter.

Io. Poore.

"John Carey, fon and heir of Henry Carey, fourth Baron Hunfdon and firt Vifcount Rochford and Earl of Dover. John Carey fucceeded to his father's honours, 1668 . Died, 1677 . See note 18. 


\section{The Lord Saint-Johns Regiment.}

Col. Oliver L. St. John. ${ }^{12}$

Liev. Col. Tho. Effex.

Ser. Ma. Ed. Andrews.

\section{Captains.}

Timo. Neale.

Oliver Beecher.

Jo. Harvie.

Lewis Pemberton.

Tho. Miles.
Jo. Hilderfon.

Tho. Thorogood.

Carriage Mafter.

Tho. Greene.

Quarter Mafter.

William Walwin.

Lievtenants.

Theo. Paholigus. ${ }^{13}$

12 Oliver Saint John, eldeft fon of Oliver Saint John, fourth Baron Saint John, who was created Earl of Bolinbroke, co. Lincoln, Dec. 28, 1624 ; was fummoned to Parliament in his father's barony of Saint John. Slain at Edge Hill, O\&t. 23,1642 .

${ }_{13}$ A member of the family of Palæologus of Landulph, co. Cornwall, who were a branch of the Imperial houfe of Conftantinople. The hiftory of this family, the laft remnant of a race with which are connected fo many hiftorical affociations, has not met with the attention it deferves. The Englifh Palæologoi have long been extinct in the male line, both here and in the Weft Indies, to which fome of the members of the family emigrated. Their blood, tranfrnitted through females, doubtlefs yet flows in the veins of many a Devonthire and Cornifh gentleman.

\section{"Fors non mutat genus."}

The perfon here indicated may poffibly be Theodore Palæologus, fon of Theodore Palæologus of Landulph, who died Jan. 21, 1636. This Theodore was afterwards a failor, and died at fea in 1693 , on board the Royal Charles. From his will, which was proved at Doctors' Commons, it feems that he had no iffue.

The following entry occurs in the Burial Regifter of Weftminfter Abbey. It is probable that it relates to the Theodore Palæologus of Lord St. John's Regiment.

$$
\begin{aligned}
& \text { " } 644 \text { Theodorus Pahiologus } \\
& \text { was bd near the lady St. } \\
& \text { John's tomb May 3." }
\end{aligned}
$$


Will. Boughty.

William Cafie.

Jos. Sears.

Lyon Pilkington.

Tho. Bedealls.

Edw. Carew.

Rich. More.

John Wood.

Wendy Oxford.

Provoft Mar/hall.

Robert Lucas.

Chaplain.

Jo. Vinter.
Enjignes.

Io. Marfhall.

Tho. Joy.

Edw. Gravenor.

Geo. Elliot.

Lewis Mordent.

Noah Neale.

Hen. Tayler.

Jos. Scarbrough.

Ric. Parker.

Hen. Lovell.

Chierurgion.

William Roberts.

\section{The Lord Brooks Regiment.}

Col. The Lord Brook. ${ }^{14}$

Liev. Col. Sir Edw. Peto.

S. M. Wal. Ailworth.
Captains. Tho. Fitch. Jo. Lilborne. ${ }^{15}$

For information relative to the Englin Palæologoi, fee the following:Archaologia, xviii. pp. 85-104. Chambers' Fournal, xvii. p. 24. BURN's Hift. of Foreign Refugees, p. 230 . SchомвURGK's Hift. of Barbadoes. Oldmixon's Weft Indies. Gentleman's Magazine, Jan. 1843. Lyson's Cornwall, p. 172. Notes and Queries, If Series, palim.

14 Robert Greville, fecond Baron Brooke. Slain at the fiege of Lichfield, March 2, I642.

is Son of Richard Lilburn of Thickley-Punchardon, co. Durham. An apprentice to a cloth-packer in Saint Swithin's Lane, London. Became clerk to William Prynne, in or about $1_{3} 6_{2}$. Whipped at a cart's tail from the Fleet Prifon to Weftminfter, and afterwards ftood in the pillory for having written a book againft bihops. His whole life was one long ftruggle againft authority. He died at Eltham, co. Surrey. Buried " in the New Church yard adjoining to Bedlam," Aug. 31, 1657.

John Lilburn's ftrange doings in the Ifle of Axholme, co. Lincoln, have not 
Ralph Cotsforth.

Tho. Hickman.

Nicho. Warren. Sambridge.

John Bridges.

$$
\text { Waggon-Mafter. }
$$

John Smith.

$$
\text { Quarter-Mafter. }
$$

John Hunt.

\section{Lievtenants.}

John Afhfield.

Chrift. Langton.

Daniel Hinton.

Nich. Ling.

John Matterfey.

Jo. Morrís. ${ }^{16}$

Roger Cotterell. John Gates.
..... Wivell.

William Bridges.

Provof Marhall.

William Coleman.

Enfignes.

Iohn Davis.

Iohn Warren.

Tho. Roberts.

William Taton.

Tho: Hinde.

Hum. Lyeathcok.

Jo. Peto.

Tho. Ginnings.

..... Cotton.

..... Egglefton.

Chirurgion.

Iohn Cleare.

hitherto met with the notice they deferve. See on this matter, Hift. of Thorne, 1829, I 2mo. pp. I 50-1 55. Peck's Topographical Account of the Ifle of Axholme, pp. г г7-г 20. Fohn Lilburn tried and Cafl, 4to. 1653, pp. 84-9o. Arms, argent, three water bougets fable.

${ }^{16}$ It is not improbable that this perfon is the John Morris who defended Pontefract Caftle during its laft fiege. It is known that he had ferved the Parliament, but was left out of the new army after the felf-denying ordinance, as "his life of great licence kept not his reputation with the new officers." Pontefract furrendered, March 22, 1649 . Morris, the governor, was excepted from mercy; he efcaped, however, for a time, by charging through the encmies' lines on horfeback, but was captured about ten days afterwards in Lancahire. Tried at York for high treafon, Aug. 16, 1649. Hanged, Aug. 23. His body refts in Wentworth Church, co. York, near to the grave of his old mafter the Earl of Strafford.

Arms, azure, three eagles difplayed, or, on a canton argent, a caftle, gules.DUGDALE's Vifit. of Yorkfhire, r66 5, 1 666, p. 267. Commons' fournals, vi. p. 174. 


\section{The Lord Mandeviles Regiment.}

Col. Hen. L. Mandevill. ${ }^{17}$ L. Col. Jo. Parkinfon.

Ser. Ma. Iohn Drake.

Captaines.

Fran. Wilfon.

Hen. Samerfter.

Edw. Watts.

Robert Goodwin.

Robert Palmer.

Dan. Redman.

Ofborn Williams.

Provof-Marfhall.

Iohn Turner.

Carriage-Mafter.

Robert Oufby.

\section{Lievtenants.}

.... Turkington.

John Hofkins.

Roger Whetftone.

Fran. Ballard.

Hen. Worth.
Io. Rofe.

Bridges Bufhell.

Nich. Dibdale.

Hugh Beefton.

James Blodwell.

Chaplain.

Simon Afh.

Quarter-Mafter.

Nich. Wood.

Enfignes.

Ja/per Goodwin.

Nath. Walmfly.

Tho. Davies.

Io. Ramfey

Cha. Davies.

Tho. Goodwin.

Math. Milbourn.

...... Fleming.

Iohn Daily.

Chirurgion.

William Stannard.

17 Edward Montague, fon and heir of Henry Montague, firt Earl of Manchefter, was educated at Cambridge. M.P. for Huntingdon in the firft Parliament oi Charles I. One of the Commiffioners to treat with the Scotch, 1640. Defeated the Earl of Newcaftle at Horncaftle, co. Lincoln, June, 1643. Took Lincoln Caftle by ftorm, May 5, 1644, capturing therein Sir Francis Fane, the governor, Sir Charles Dallifon, and others. Died at Whitehall, May 5, 1671, aged 69 years. 
The Lord Roberts his Regiment.

Col. John L. Roberts. ${ }^{18}$

L. Col. Will. Hunter.

Ser. M. Alex. Hurry.

\section{Captaines.}

James Witcherly.

Io. Walker.

Io. Mercer.

Mark Grimes.

John Mill.

Ionath. Elliot.

Iam. Fookes.

$$
\text { 2uarter-Mafter. }
$$

William Rawlins.

\section{Provof Marßall.}

Hum. Franouth.

\section{Lievtenants.}

Geo. Graden.

Tho. Keckwick.

Rich. Baron.

Walter Heys.

Jo. Melvin.

Tho. Turrell.

Barnard Smelomb.

Io. Spooner.

Dan. Trevor.

Carriage-Mafer.

Thom. Higgins.

Chaplain.

Dr. Calibut Downing. ${ }^{19}$

18 John Robartes, fecond Baron Robartes of Truro, co. Cornwall. Succeeded to his father's title, $16_{34}$. Created Vifcount Bodmin, co. Cornwall, and Earl of Radnor, July 23, 1679. Died, at Chelfea, July 17, 1685. Buried at Lanhedrock, co. Cornwall.

${ }_{19}$ The eldeft fon of Calybute Downing of Shennington, co. Gloucefter. Lord of the Manors of Sugarfwell and Tyfoe, co. Warwick. A commoner of Oriel College, Oxford, 1623. Rector of Hickford, co. Bucks, and of Weft Ildfey, co. Berks. Exchanged the latter rectory for that of Hackney, near London. Died at Hackney, 1644. Calybute Downing had the misfortune to be the father of George Downing, a man notorious for one of the blackelt acts of perfidy to be found in our annals. George Downing began life as a minifter of religion, having been Colonel Okey's Chaplain. He was afterwards " a foldier in Scotland, and at length fcout Mafter general there, and a burgefs for feverall corporations in that kingdom." He became loyal at the Reftoration, and was difpatched as envoy extraordinary into Holland, where, under the promife of fafety, he trepanned Colonel Okey, Miles Corbet, and Colonel Barkftead into his power, and fent them over to England to fuffer death for having 


\section{Enfignes.}

Tho. Roufe.

William Hender.

Alex. Tulidaffe.

Cuthbert Farley.

Ios. Normington.

Iohn Skudamore.
Mark Grimes.

Edw. Genings.

Ben. Groome.

Iohn Merrick.

Chirurgion.

Edw. Cooke.

\section{Colonell Cholmlies Regiment.}

Col. Sir Hen. Cholmly. ${ }^{20}$

L. Col. Launce Alured.

Ser. M. Th. Southcot.

\section{Captaines.}

Henry Ienkins.

William Bateler.

Henry Katcofe.

Goddard Leigh.

Richard Jones.

Robert Hunt.

Iohn Bury.

\section{Provoft Marßall.}

Nicholas Garth.21

\section{Lievtenants.}

Mich. Jobfon.

Mich. Dane.

William Wellin.

George Fulwood.

Io. Shanke.

Io. Fifher.

...... Andrewes.

...... Goodwin.

Smith Wilkinfon.

Chaplain.

Adoniram Bifield.

been members of the commiffion for trying King Charles I. George Downing was created a Baronet, July, 1663.

${ }^{20}$ The fecond fon of Sir Richard Cholmley of Whitby, co. York. He twice befieged his brother, Sir Hugh Cholmley, who had deferted the fervice of the Parliament, in his caftle of Scarborough. Survived the Reftoration, and is faid to have been active in bringing about that event.

${ }^{21}$ Nicholas Garth was probably a member of the family of Garth of Headlam, co. Durham. The name Nicholas does not occur in the very carefully compiled pedigree by John Richard Walbran, Efq., F.S.A. Arms of Garth of Headlam and of Bolham, co. Durham, or, two lions paffant, in pale, between three croflets fitchee, fable.-WALBRAN's Gainford, p. 1 10. 
Enfignes.

Hugh Philips.

George Rotherham.

Hen. Burkfley.
Tho. Apleby.

William Weft.

Barth. Burrell.

Heraid Slrrimfhaw.

\section{Colonell Hollis his Regiment.}

Col. Denzell Hollis. ${ }^{22}$

L. C. Hen. Billingley.

Ser. Maj. Jam. Quarls. ${ }^{23}$

Captaines.

Allen Povey.

William Barke.

Richard Lacy.

George Harlock.

Jo. Francis.

William Burles.

..... Bennet.

\section{Lievtenants.}

Rích. Parker.

Jo. Court.
Geo. Hampfon.

Roger Noard.

Io. Owen.

Tho. Lawrence.

...... Samuel.

Tho. Churchman.

\section{Enfignes.}

Ralph Walfet.

Rawley Willis.

Edw. Neve.

Tho. Cattorill.

Robert Willoughby.

Tho. Clement.

Alexander Payard.

\section{Colonell Bamfields Regiment.}

Col. William Bamfield. ${ }^{24}$

Ser. Ma. Sam. Price.

L. C. Sir Ro. Wingfield.

22 Denzill Holles, younger fon of John Holles, firft Earl of Clare. One of the five members charged with high treafon, I641. One of the commiffioners fent by Parliament to wait on Charles II. at the Hague, I 660.

${ }^{23}$ Killed at Brainsford, Nov. 12, 1642 .-Micro-Chronicon.

24 Sir William Bamfield foon joined the King's fervice, and was taken prifoner at Arundel by Sir William Waller, Jan. 28, 1644. Affifted in the efcape of the Duke of York, 1648 . 


\section{Captaines.}

Rob. Baker.

Rich. Benfon.

Io. Ie fop.

Io. Minghaw.

Wil. Owen.

Tho. Stafforton.

..... Pawlet.

Chaplain.

..... Freeman.

Cbirurgion.

Rich. Searle.

\section{Lievtenants.}

Io. Hart.

Ambr. Cade.

Ralph Garth.

Tho. Durdo.

Tho. Latimer.

Hogan Rookwood.

Hum. Burton.
Albion Derickbore.

He. Wray.

Andrew Ball.

2uarter-mafter.

Chri. Allanfon.

Carriage-maft.

He. Beecher.

\section{Enfignes.}

Samfon Manaton.

George Wingfield.

Sym. Giggins.

Io. Roje.

Io. Browne.

William Blake.

Richard Jackfon.

Io. Price.

Fra. Barber.

Tho. Hudfon.

Provof Marhall.

Richard Gray.

Coloneli. Granthams Regiment.

Col. Tho. Grantham. ${ }^{25}$

Liev. C. Fran. Clarke.

Ser. Ma. Io. Holman.

Captaines.

Hen. Afhley.

2s Colonel Thomas Grantham reinforced the Parliamentary Army with the troop under his command the evening after Edge Hill battle. 
Sir Tho. Pigot.

Rich. Gibbs.

Tho. Rogers.

Fran. Grantham.

Geo. Slatford.

Hen. Blundell.

\section{2uarter-majt.}

H. Throckmorton.

\section{Lievtenants.}

Francis Gray.

Edw. Tetlow.

Ifaac Challys.

Thomas Lee.

Steph. Deane.

Edw. Apfeley.

Io. Blanden.

Miles Hitchcock.

Geo. Walter.
Tho. Sparrow.

Provof Mar/hall.

Robert Gibbons.

Enfignes.

Nethermill Garrard.

Tho. Browne.

Tho. Coo.

Geo. Langford.

Io. Middleton.

Henry Gurney.

Sheldon Napper.

Iob Throckmorton.

Ben. Bet fworth.

Tho. Blundell.

\section{Carriage-mafter.}

Io. Hopkinfon.

\section{Sir William Constables Regiment.}

Col. Sir W. Conftable. ${ }^{20}$

Liev. C. Rob. Grain.

Ser. M. He. Frod $\int a m$.

\section{Captaines.}

Tho. Eure.

${ }^{26}$ Sir William Conftable of Flamborough, co. York. Knighted by the Earl of Effex in Ireland, I 599. Created a Baronet, I6II. Imprifoned in the matter of Shipmoney. He was appointed one of the commiffioners for trying Charles I, and figned the death warrant. He died, $16_{55}$. With retrofpective malignity, worthy of thofe who violated the fanctity of the graves at Weftminfter, his name was excepted out of the general pardon at the Reftoration as if he had been living; thus his eftates became forfeited. Arms, quarterly, gules and vaire, over all a bend, or. 
Iam. Breckham.

Io. Fenwíck.

Simon Needham.

Ben. Cicill.

Humph. Jones.

Iam. Gray.

Provof Marhall.

Iohn Yarner.

Carriage-Mafter.

Caleb Love-joy.

\section{Lievtenants.}

Edm. Hackluit.

Io. Linch.

..... Sumner.

Io. Dugdaile.

Tho. Compton.

Hen. Pownall.

Tho. Beft.

Iacob Stringer.

..... Courtop.
Ro. Harvie.

Chirurgion.

Nath. Harris.

Chaplain.

William Sedgwick. ${ }^{27}$

Enfignes.

Jofeph Smith.

William Knight.

William Miller.

Arthur Young.

..... Lifter.

Arth. Pargiter.

..... Harecourt.

Iohn Gorge.

Tho. Roe.

Mofes Neale.

Quarter-mafter.

William Bradford.

\section{Colonell Ballards Regiment}

\section{Col. Tho. Ballard. ${ }^{2 \$}$}

Ser. Ma. Wil. Lower.

Liev. C. Fran. Martin.

27 Son of William Sedgwick of London. Entered Pembroke College, 1624; was chief preacher of the city of Ely during the Commonwealth. He was called, from his zealous labours, "the apoftle of the ine of Ely," but gave up his preferment on the paffing of the A\&t of Uniformity.-Wood's Athena Oxon. in voce.

${ }^{28}$ Commander-in-chief in Lincolnthire for the Parliament, 1643. Afterwards entered the Royal fervice. 


\section{Captaines.}

Tho. Middleton.

Fran. Foukes fen.

Edward Allen.

Edw. Primrofe.

Pet. Momford.

Io. Browne.

Rob. Noyes.

\section{Quarter-maft.}

Io. Lamfdie.

\section{Lievtenants.}

Leon Moreton.

Io. Hughes.

Dan. Redman.

Iohn Lookar.

Fran. Fowke jun.

Fran. Bowyler.

Edw. Norbury.
Robert Davies.

Tho. Brandy.

Waggon-mafter.

Jere. Burleigh.

$$
\text { Enfignes. }
$$

Hen. Collingwogd.

William Fowles.

Cha. Parker。

Robert Purpell.

Henry Higgins.

Tho. Axftell.

Io. Hardy.

Edw. Wett.

William Ogee.

William Garfoot.

Provof Marhall.

Ben. Ludlow.

\section{Sir William Fairfax his Regiment.}

Col. Sir William Fairfax. ${ }^{29}$

L. Col. Will. Monings.

Ser. Ma. Jarvis Paine.

\section{Captaines.}

Francis Rogers.

${ }^{29}$ Sir William Fairfax of Steeton, co. York, Knight, eldeft fon of Sir Philip Fairfax of Steeton, by his wife Frances, daughter of Edmund Sheffield, third Baron Sheffield of Butterwick, co. Lincoln, and firt Earl of Mulgrave. Sir William Fairfax married Frances, daughter of Sir Thomas Chaloner, Knight, of Guirborough in Cleveland, fifter of Thomas Chaloner and James Chaloner, who were members of the commiffion for trying King Charles I.

Sir William Fairfax was flain before Montgomery Caftle, O\&t. 27, 1644.THORESBY's Ducatus Leodinen/is, p. 67. STONEHOUSE's Ifle of Axholme, p. 262. 
Edward Ondingfell.

Thomas Rufh.

Michael Bland.

Robert Wilfhiere.

..... Leighton.

William Trunke.

$$
\text { Quarter-Mafer. }
$$

Thomas Tyrer.

Cbirurgion.

James Winter.

\section{Lievtenants.}

David Goldfmith.

Thomas Whitney.

George Tirwhit. ${ }^{30}$

Iohn Caldecott.

William France.

Thomas Rutton.

Francis Bland.
George Gifford.

William Llewellin.

Iohn Fofter.

Provof Marßall.

Henry Fifher.

$$
\text { Enfignes. }
$$

Iohn Read.

Atwell Needham.

Iohn Lloyd.

Richard Adams.

Richard Upton.

Edward Otter.

Iames Sleigh.

Io. White.

Theophilus Willey.

Samuel Kenarick.

\section{Carriage-Mafter.}

Henry Ward.

\section{Colonell Charles Essex his Regiment.}

Col. Charles Efjex. ${ }^{31}$

L. C. Adam Coningham.

Ser. Ma. .......

${ }^{30}$ George Tyrwhitt was a member of the old and illuftrious houfe of Tyrwhitt of Kettilby and Stainfield, co. Lincoln. His name does not occur in the printed pedigree. Many of the members of this family were royalifts ; fome others were, in feeling at leaft, on the popular fide. A privately printed hiftory of this family exifts.

31 Churles Effex, fon of Sir William Effex of Lambourne, co. Berks (who was himfelf a captain in his fon's regiment). He had been a page to the Earl of Effex, through whofe influence he obtained a command in the Low Countries. Killed by a muket thot at Edge Hill, Odt. 23,1642 , where his father was taken prifoner by the King's forces. 


\section{Captaines.}

William Roberts.

Jo. Ienkins.

Francis Hall.

William Frederick.

Io. Hafelwood.

Samuel Loftus.

Sir Wil. Effex.

2uarter-maft.

Rog. Waje.

\section{Lievtenants.}

Francis Hall.

Edward Barnewell.

Iames Webb.

Ralph Williams.

Barth. Elliot.

Walraven Hemert.

Chriftoph. Crow.

Chriftoph. Chidley.

Iames Burrell.
Daniel Robinfon.

Chaplain.

Samuel Wells.

Enfignes.

Io. Shipman.

Leonard Hawkins.

Io. Wheeler.

Io. Warkins.

Tracey Smart.

Io. Withers.

William Stratford.

Thomas Fitz.

Rob. Shergall.

Rich. Thornehill.

Provoft Mar.

Martin Benthin.

Cbirurgion.

Io. Browne.

Colonell John Hambden his Regiment.

Col. John Hambden, ${ }^{32}$

Liev. C. Wagftaff.

Ser. Ma. Will. Barriff.
Captaines.

Richard Ingoldefbe. ${ }^{33}$

${ }^{32}$ John Hampden, eldeet fon of William Hampden of Hampden, co. Bucks, by his wife Elizabeth, fecond daughter of Sir Henry Cromwell of Hinchinbroke, co. Hunt. Wounded at Charlgrove field, June 18, 1643; died fix days afterwards.

s3 Richard Ingoldiby of Lenthenborough, co. Bucks. One of the commiffion- 
.... . Nicholls.

...... Arnett.

John Stiles.

..... Raymant.

Robert Farrington.

..... Morris.

Lievtenants.

Henry Ifham.
A Dutchman.

..... Shorter.

Enfignes.

Edward Willet.

Laurence Almot.

Chaplain.

William Spurftow.

How the number of Souldiers in each Regiment of Foot are divided under their Jeveral Captaines.

The Colonells company . . . . 200

The Lievtenant Colonells company 160

The Serjeant Majors company • 140

Seven Captaines . . . . . 700

Every Regiment confifts of 1200 . Befides Officers.

The Names of the Counsell of Warre.

Sir John Mericke, Prejident.

Sir William Belfore, Lievtenant-Generall of the Horfe.

Colonell Wardlaw.

Colonell Grantham.

Sir William Conftable.

Philibert Emmanuel de Boyfe, Lievtenant Generall of the Artillery. Doktor Ifaac Dorifla, Advocate of the Army.

ers for the trial of Charles I. His fignature is attached to the death warrant. Pardoned at the Reftoration, and created a Knight of the Bath. His refidence was at Waldridge, in the parifh of Dinton, near Aylefbury. He was buried in Hartwell Church, Sept. 16, 1685.-NOBLE's Houfe of Cromwell, vol. ii. p. 189 . 
HE Lift of the Troops of Horfe, under the Command of William Earle of BeDFord : Each Troop confifting of 60 Horfe ; befides 2 Trumpeters, 3 Corporalls, a Sadler, and a Farrier.

\section{Colonells and their Officers.}

Colonell, William Earle of Bedford.

Major.

Chirurgion, Hugh Ward. Colonell, Sir Wil. Belfore. Major, Jo. Urrey.
Chirurg. James Swright.

Colonell, Bazil Lord Fielding. ${ }^{3 *}$ Major, Robert Beckill. Colonell, Lord Willoughby of Parham. ${ }^{35}$

Colonell, Sir William Waller. ${ }^{36}$

34 Bazil Fielding, fon and heir of William Fielding, firft Vifcount Fielding, and Earl of Denbigh, fought in the Parliamentary army at Edge Hill, his father, the Earl of Denbigh, ferving as a volunteer on the fide of the King. William, firf Earl of Denbigh was mortally wounded in the Royal Army near Birmingham, April 3, 1643, and now lies buried at Monk's Kirby, co. Warwick. Bazil, the fecond Earl, died Nov. 28, 1685 .

${ }^{35}$ Francis Willoughby, fifth Baron Willoughby of Parham. He took Gainßborough by ftorm, July 16,1643 , getting " great ftore of ammunition and armes in the towne, a good part of the Earl of Kingfton's Treafures; one writes more gold than his red bever hat will hold."-The Kingdom's Weekly Intelligencer, 18-25, July, 1643, as quoted in STARK's Hift. of Gainforough, 1843, p. 130.

"The Lord Willoughby kept the town afterwards againt the Earl of Newcaftle's forces till overpowered with numbers he was forced to furrender it on honourable conditions."-WHITELOCK, i. 209.

Drowned in the Weit Indies, 1666.

${ }^{36}$ Son of Sir Thomas Waller, Conftable of Dover Caftle. Had ferved in the Low Country wars. He was defeated at the battle of Lanfdowne, July 5, 1643. Died Sept. 9, 1669. 
Major, Horatio Carew. Chirur. James Bricknell. Colonell, Edwin Sands.

I Troop.

The Lord Generalls.

Liev. W. Anfell.

Cornet, John Palmer.

2.

C. Sir W. Belfore.

L. Iohn Meldram.

C. William Jewty.

\section{3.}

C. L. Grey, Groub.

L. Sim. Matthews.

C. Th. Barington.

Q. Da. Madox.

\section{4.}

C. Earle of Peterb.

L. Herb. Dlaugherd.

C. Will. Cheney.

5.

C. Lord Say.

L. Hen. Atkinfon.

C. John Croker.

Q. Robert Parin.
Major, Alex. Douglas. Chirurgion, John Anthony.
6.

C. Lord Brooke.

L. Richard Croffe.

C. Rob. Lifbourne.

Q. Io. Okey. $\nmid$

7.

C. L. Haftings ${ }^{37}$

L. Tho. Gratwick.

C. Hen. Ayfluye.

Q. Tho. Mejham.

8.

C. L. St. John.

L. Marmad. Couper.

C. Oliver Cromwell.

Q.W. Wallen.

\section{9.}

C. L. Stanford.

L. Samuel Boja.

C. Cap. Ric. Bingley.

Q. Tho. Vaves.

Io.

c. L. Fielding.

37 Ferdinando Haftings, fon and heir of Henry Haftings, fifth Earl of Huntingdon. Born at Amby de la Zouch, Jan. 18, x608. Died Feb. 15, 1655. 

L. Reeve Bayley.
C. Tho. Brudnell.
Q. William Tovey.

I I .

C. L. Wharton.

L. Ralph Whiftler.

C. Peter Ware.

Q. Nich. Batterfby.

I2.

C. Lord Willoughby of P.

L. Hum. Brookbank.

C. Tho. Hickman.

I3.

C. Lord Grey.

Q...... Madox.

\section{I4.}

C. Jam. Sheffeld. ${ }^{33}$

L. Tho. Jewks.

C. Rich. Maunder.

Q. Rich. Iolly.

I 5 .

C. Sir W. Waller.

L. Ric. Newdigate.

C. Foulke Grevill.
Q. Fran. Grey.

16.

C. John Gunter.

L. Hen. Strelly.

C. James Godderd.

Q. Edw. Pudfey.

17.

C. Will. Pretty.

L. Mat. Ploughman.

C. Miles Morgan.

Q. Nich. Smith.

I8.

Rob. Burrell.

L. John Greene.

C. Nathaniel Weft.

Q. Thomas Eliot.

19.

C. Francis Dowett.

L. Hen. Saderfon.

C. Tho. Gore.

Q. John Otter.

20.

C. Iames Temple. ${ }^{39}$

s8 Son of Edmund Sheffield, firft Earl of Mulgrave, by his fecond wife, Mariana, daughter of Sir William Irwin, Knight.

${ }_{39}$ This is probably the James Temple who was one of the commiffioners for the trial of King Charles I. He was tried after the Reftoration, but the extreme penalty of the law was not inflicted. Suppofed to have died in the Tower. 

L. William Baker.
C. Carax Ling.
Q. Fran. Sharpe.

2 I.

C. Iohn Bird.

L. Samuel Bofa.

C. Ambr. Rooke.

Q. Jonathan Finch.

22.
C. Mathew Draper.
C. Iohn Strelly.
Q. Abraham Carter.

23.

C. .... Dimock.

24.

C. Horatio Carey.

L. Jonas Vandrufick.

C. George Hutton.

25.

C. Iohn Alured. ${ }^{40}$
26.

C. Iohn Neale.

L. Rob. Brufe.

27.

C. Iohn Hamond.

C. William Gill.

Q. I fack Cavaler.

28.

C. Ed. Ayfcough.

L. Thomas Mofley.

C. .... Sayer.

Q. .... Clarke.

29.

C. Alex. Pym.

L. Arnold Haward.

C. Ric. Compton.

Q. Ralph Romitree.

30.

C. Iohn Hotham. ${ }^{41}$

${ }^{40} \mathrm{John}$ Alured was a Yorkfhireman, probably a native of Hedon in Holdernefs, which borough he reprefented in the Parliament of 1640 . He was one of King Charles I.'s judges, and figned the warrant for his execution. Although he died before 1660 , his name was put in the act of attainder that his property might be forfeited. His brothers, Lancelot and Matthew Alured, were active on the fide of the Parliament.

${ }^{41}$ Sir John Hotham, Knight, was created a baronet, January 14, 1621. He was Governor of Hull at the breaking out of the Civil War, and refufed King Charles I. admittance into that town, March 23, 1642, for which he was proclaimed a traitor by the King. He and his fon, Sir John Hotham, Knight, 
31 .

C. Arthur Evelin.

L. C. John de la Hay.

32.

C. Geo. Thompfon.

L. John Cofhe.

C. Iohn Upton.

Q. Will. Couje.

33 .

C. Edwin Sandys.

L. John Cockaine.
34 .

C. Anth. Milemay.

L. Hen. Hatcher.

C. Sam. Cofworth.

Q. Th. Varnon.

\section{5 .}

C. Ed. Kyghley.

L. W. Cooker.

C. Tho. Loftus.

Q. Alex. Winchefter.

$$
36 .
$$

C. Nath. Fines. ${ }^{42}$

were afterwards difcovered to be correfponding with the Earl of Newcaftle and other Royalifts, for which acts they were tried and fuffered death, 1645 .

${ }^{2}$ Nathaniel Fienes, fecond fon of William, eighth Baron, and firf Vifcount Say and Sele, by his wife Elizabeth, daughter of John Temple of Stow, co. Bucks. He was one of the committee nominated by Parliament to accompany Charles I. into Scotland. Defeated by Prince Rupert near Worcefter, Sept. 23, I642. Governor of Briftol, which he furrendered to Prince Rupert, July 26,1643 , for which act of reputed cowardice he was tried and condemned to death, but pardoned. Keeper of the Great Seal to the Protector Richard Cromwell. He married Elizabeth, daughter of Sir John Elliot of Port Elliot in Cornwall. Died at Newton Toney near Salifbury, Dec. 16, 1669.

The cavaliers made merry over the defeat of Fienes and his followers before Worcefter. More than one piece of doggerel relating to this adventure has come down to modern times:-

"Thither came Fines, with armes complete,

"The town to take and Byron defeat,

"Provifions were made but he ftaid not to eat,

Which no body can deny.

"But as foon as he heard our great guns play,

"With a flea in his ear he run quite away,

" Like the lawfull begotten fon of Lord Say,

Which no body can deny."

H 

37 .
C. Edw. Berry.
L. C. Ed. Saunders.
C. Tho. Billiard.
Q. Hen. Woodnoth.

38.

C. Alex. Douglas.

39.

C. Tho. Lidcott.

L. Rob. Stradling.

40.

C. Tho. Hamond.

L. John Lindfey.

C. Mi. Wanderford.

\section{1.}

C. John Dulbeir.

L. Wil. Framton.

C. H. Vánbraham.

Q. Io. Downeham.
42.
C. Francis Fines.
L. Iames Moore.
C. Henry Fines.
Q. George Malten.

\section{3.}

C. S. A. Hafelwrick. ${ }^{43}$

L. Jervis Brakey.

C. Tho. Horton.

Q. Zach. Walker.

44.

C. S. Walt. Earle.

L. Ed. Iohnfon.

Q. Paul Scooler.

$$
45 .
$$

C. Jo. Fleming.

L. Robert Kirle.

C. Ed. Fleming.

Q. B. Blackborow.

$$
46 \text { : }
$$

C. Ar. Goodwin.

${ }^{43}$ Sir Arthur Hafilrigge, Bart, eldeft fon of Sir Thomas Hafilrigge of Nofeley, co. Leicefterhire. Brought forward the bill in the Houfe of Commons for the attainder of the Earl of Strafford. One of the five members accufed by King Charles I. of high treafon. The foldiers of Sir Arthur's troop were " fo prodigiounly armed, that they were called by the other fide the regiment of lobfters becaufe of their bright iron thells."-CLARENDON's Hift. p. 402. They were, neverthelefs, defeated by the Royal army at Roundway Down, July 5 , 1643, where Sir Arthur was badly wounded. He was one of King Charles I.'s judges, but did not fign the death warrant. He died in the Tower fhortly after the Reftoration. 

L. Iohn Browne.
C. Peter Palmer.
Q. William Jucey.

\section{7.}

C. Rich. Grenvile.

L. Cha. Fountaine.

C. Jo. James.

Q. Alex. Davifon.

\section{8.}

C. Tho. Terrill.

L. William Spry.

C. Iofeph Ianes.

Q. Ed. Throwley.

\section{9.}
C. Iohn Hale.
L. Chenie Fuller.
C. I. Midehoope.

Q. Michael Hale.

50.

C. H. Milmay of G. ${ }^{44}$

L. Hen. Gibb.

C. Rob. Milmay.

Q. Edm. Hadon.

\section{$5 \mathrm{I}$.}

C. Will. Balfoore.

C. George Weft.

\section{2.}

C. George Auftin.

53.

C. Adrian Scroope. ${ }^{45}$

L. William Day.

C. Max. Vetty.

Q. Henry Nuby.

14 Henry Mildmay of Graces, co. Effex, a relative of Sir Henry Mildmay, Knight, of Mutho, co. Effex, who was one of Charles I.'s judges, but did not fign the warrant for execution.

45 A member of one of the moft important of the knightly families of England. The Scropes were long fettled at Bolton, co. York; other branches of the houfe have dwelt at Mafham, co. York; Cockrington; co. Lincoln; Caftle-Combe, co. Wilts, and Wormfley, co. Oxford, of which laft Adrian Scrope was a member. He ferved the Parliament faithfully throughout the war, and afterwards fat as one of the commiffoners for trying the King, whofe death warrant he figned. . For this he fuffered death after the reftoration. Arms, azure, a bend, or.

The prefent repreprefentative of the houfe of Scrope is Simon Thomas Scrope, Efq., of Danby, co. York, the claimant of the Earldom of Wilthire.-Shirley's Noble and Gentlemen of England, p. 287. Noble's Regicides, vol. ii. p. 200. Blore's Rutlandfhire, fol. 1811 , pp. 5.8. 


\section{4.}

C. Herc. Langrifh.

L. Io. Dingley.

C. J. de la Blancheur.

Q. Io. Ealfinan.

55.

C. Edw. Wingate.

L. Tho. Evans.

C. Hen. Daldorne.

Q. Io. Whitebread.

$$
5^{6 .}
$$

C. Edw. Baynton.

57.

C. Ch. Chichefter.

L. Jo. Hyde.

C. Edward Weeks.

Q. Richard Gourd.

58.

C. Hen. Ireton. ${ }^{46}$

L. Jo. de Gennis.

C. Samuel Clarke.
Q. Chrift. Brifton.

59.

C. Walt. Long.

L. Nic. Batterfby.

C. Coniers Cooper.

Q. Walt. Harcourt.

60.

C. John Fines.

L. Jo. Carmichaell.

C. Edw. Walley.

Q. Wil, Bugflock,

$6 \mathrm{I}$.

C. Fr. Thompfon.

L. Tho. Elliot.

C. Vincent Corbet.

Q. Phil. Barley.

62.

C. Edmond Weft.

63.

C. Sir Robert Pie.

46 Henry Ireton, eldeft fon of German Ireton of Attenton, co. Notts. Born, 1610. Gentleman commoner of Trinity College, Oxford, 1626. B.A. 1629. Married Bridget, eldeft daughter of Oliver Cromwell, I646. Taken prifoner at the battle of Nafeby, but made his efcape during the confufion of the Royalifts' retreat. Made prefident of Muniter, Jan. 1650. Died of the plague before Limerick, Nov. 36,1651 . His body was brought to England and lay in fate at Somerfet Houfe. Buried in Henry VII.'s Chapel, Weftminfter Abbey, Feb. 6, 1652. After the Reftoration, his body was taken up and expofed upon a gallows at Tyburn. The trunk was there buried, the head fet upon Weftminiter. Hall.-Noв LE's Cromwsll, vol. ii. pp. 319.323. 
64.

C. Thomas Hatcher.

65.

C. Robert Vivers.

66.

C. William Anfelme.

$$
67 .
$$

C. Oli. Cromwell. ${ }^{47}$

L. Cutb. Baildon.

C. Jos. Waterhoufe.

Q. Io. Difbrow.

68.

C. Robert Kirle.

L. Ch. Fleming.

C. Iames Kirle.

Q. Iohn Ball.

69.

C. Sir William Wray.

70.

C. Wil. Pretty.
L. Mat. Plowman.

C. Miles Morgan.

Q. Ant. Arundel.

$7 \mathrm{I}$.

C. Sir Io. Sanders.

L. Wil. Wardley.

C. Math. Pedar.

Q. John Harding.

72.

C. Thomas Temple.

73.

C. Valen.Watton. ${ }^{43}$

L. Jarvis Bonner.

C. ..... Watton.

Q. Obadiah Crifp.

74.

C. Sir Faithfull Fortefcue .

75.

C. Simon Rudgley.

L. Lew. Chadwick.

C. Edward Fines.

47 Afterwards His Highnefs the Lord Protector. Oliver Cromwell, whofe name occurs as a cornet in Lord St. John's troop, No. 8, is the eldeft fon of Oliver Cromwell, Efq., M.P. for Cambridge, fo foon to be famous. Oliver Cromwell, junior, was baptized Feb. 1623. He died, or was killed during the war.-CARLYLE's Cromwell, i. p. 92.

18 Valentine Wauton, or Walton, of Great-Stoughton, co. Hunt. Married Margaret, the fifter of Oliver Cromwell, the Protector; was a member of the Court of High Commiffion for trying the King, and figned the warrant. Died in Flanders, $166 \mathrm{r}$. 
Dragooneers, Each Troope consisting of IOO Horse, Besides the Officers.

\begin{abstract}
I.
Colonell, and Cap. Jo. Browne. Major \& Cap. Nath. Gordon. Sir John Browne, Captaine.
\end{abstract}

\section{2.}

Cap. Rob. Mewer.

Lievt. Thomas Mewer.

Cor. Nicholas Mewer.

3.

Cap. William Buchain.

Cap. Robert Marine.

Lievt. Francis Bradbury.
Quarter-mafter, Iohn Blackman. Provoft-Marfhall, Daniel Lyon.

$4 \cdot$.

Cap. Sir Anthony Irby. Lievt. William Patrick. Cor. Richard le Hunt.

$$
5 .
$$

Colonell, James Wandlo. Lievt. George Dunlas. Cap. Alexander Nerne. Cap. Iohn Barne. Cap. Iames Stenchion. Chirurgion, Iames Heithley.

Thofe Officers that are not mentioned in the $\mathrm{fe}_{\mathrm{Lifts}}$, have not as yet received their Commifions by reafon of their fuddain imployment in the Expedition. 
A true Copie of the Inftructions agreed upon by the Lords and Commons affembled in Parliament, and Jent to his Excellency the Earle of EJfex Lord Generall of the Army, concerning the advancing of his Forces towards His Majefty, E'c.

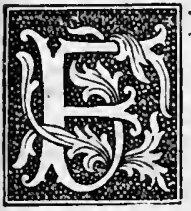

IRST you fhall carefully reftraine all Impieties, Prophanenefe, and Diforders, Ryot, Infolence, and Plundering in your Souldiers, as well by ftrict and fevere punifhment of Juch offences, as by all other meanes which you in your wifedomes hall thinke fit.

Secondly, your Lordfhip is to march with fuch forces as you thinke fit towards the Army, raifed in his Majefties Name againft the Parliament and Kingdome, and with them, or any part of them, to fight at fuch time and place as you Shall judge to conduce to the peace and fafety of the Kingdom; And you fhall ufe your utmoft endevours by Battaile or otherwife to refcue his Majefties perfon, and the perfons of the Prince, and Duke of Yorke, out of the hands of thofe defperate perfons who are now about them.

Thirdly, you fhall take an opportunitie in fome fafe and honourable way, to caufe the Petition of both Houfes of Parliament herewith fent unto you, to be prefented unto his Majeftie, and if his Majeftie fhall pleafe thereupon to withdraw himfelfe from the forces now about him, and to refort to the Parliament, you fhall caufe all the fe forces to difband, and fhall Jecure and defend his Majeftie with a fufficient ftrength in his returne.

Fourthly, you fhall publifh and declare, that if any, who have been feduced by the falfe afperfions caft upon the proceedings of the Parliament, as to affift the King in the acting of tho $\int e$ dangerous Counfels, Shall willingly within ten dayes after fuch publication in 
the Army, returne to their dutie, not doing any hoftile aff withi: the time limited, and joyne them felves with the Parliament, in de fence of Religion, his Majefties perfon, the Liberties and Lawes o the Kingdome, and priviledges of Parliament, with their perfon and Eftates, as the Members of both Houfes, and the reft of thi Kingdome have done: That the Lords and Commons will be ready upon their fubmiffion to receive fuch perfons in Juch manner as they fhall have caufe to acknowledge they have been ufed with clemency and favour: Provided, that this fhall not extend to admit any mar into either Houfe of Parliament who ftands Jufpended, withoul giving Jatisfaction to the Houfe whereof he fhall be a Member : and except all perfons who ftand impeached, or particularly Voted in either Houfe of Parliament for any delinquency what foever; Excepting likewife fuch Adherents of tho e e who ftand impeached in Parliament of Treafon, as have been eminent perfons and chiefe Actors in thofe Treafons; And except the Earle of Briftoll, the Earle of Cumberland, the Earle of New-Caftle, the Earle Rivers, Secretary Nicholas, Mafter Endimion Porter, Mafter Edward Hide, the Duke of Richmond, the Earle of Carnarvan, the Lord Vifcount Newarke, the Lord Vifcount Faulkland, being one of the principall Secretaries of State to his Majeftie.

Fifthly, you fhall apprehend the perfons of all the e who ftand impeached in Parliament, or have been declared Traytors by both or either Houfe of Parliament, or other Delinquents, and you fhall fend them unto the Parliament to receive condigne punifhment according to their offences.

Sixthly, you Jhall receive the Loanes, or Contributions of Money, Plate, or Horfe from all his Majefties loving Subjects, which they Shall be willing to make for the Jupport of the charge of the Army, and better difcharge of the fervice of the Common-wealth; And you Jhall certifie all fuch Jummes of Money, and the value of Juch Horfes, that the perfons thereupon may have the publique faith for payment to be made unto them, as to others of his Majefties Subjects upon the fubfcription of Money, Plate, and Horfe. 
Seventhly, you fhall carefully proted all his Majefties loving Subjects from rapine and violence by any of the Cavaliers, or other of his Majefties pretended Army, or by any of the Souldiers of the Army which you command; and you fhall caufe the Armour and Goods of any perfon to be reftored to them from whom they have been unjuftly taken.

Eighthly, you fhall obferve fuch further Directions and Inftruetions as you from time to time receive from both Houfes of Parliament.

A Lift of his Majefties Navie Royall, and Merchants Ships; Their Names, Captaines, and Lievtenants, their Men and Burthens in every one, now setting forth for the Guard of the narrow Seas, and for Ireland this yeare 1642 .

The Kings Majesties Ships: The Names of Captaines, and Lievtenants, Ships, Men, and Burthens.

I.

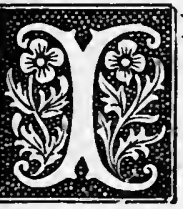

N the James, Robert Earle of Warwicke, Vice-Admirall, Mafter Slingfby Lievtenant, $260 \mathrm{men}$, burthen 875 tun.

2. In the Saint George, William Batten Captaine, Mafter William Smith Leivtenant, $260 \mathrm{men}$, burthen, 792 tun.

3. In the Raine-Bow, Sir John Menns Captaine, Mafter Lutten Lievtenant, 260 men, burthen $72 \mathrm{I}$ tun.

4. In the Reformation, Sir David Murrey Captaine, Mafter Standfbuy Lievtenant, 260 men, burthen 731 tun. 
5. Viktory, Captaine Fogge Captaine, Mafier Fogge Lievtenant 240 men, burthen 742 tun.

6. Henrietta Maria, Captaine Hatch Captaine, Mafter Wattes Lievtenant, 250 men, burthen 793 tun.

7. Unicorn, Captaine Frenchfield Captaine, Mafter Sommerfton Lievtenant, 250 men, burthen 767 tun.

8. ...... Charles Swanley Captaíne, Mafter Darey Lievtenant, 250 men, burthen 8 IO tun.

9. Vantguard, Captaine Blith Captaine, Mafter Blith Lievtenant, 250 men, burthen $75 \mathrm{I}$ tun.

10. Entrance, Captaine Owen Captaine, Mafter Bowen Lievtenant, 160 men, burthen 539 tun.

II. Garland, Captaine Stingfby Captaine, Mafter Walters Lievtenant, 170 men, burthen 767 tun.

I2. Lyon, Captaine Prife Captaine, Mafter Hill Lievtenant, 170 men, 602 tun.

13. Antelope, Captaine Burley ${ }^{49}$ Captaine, Mafter Willeby Lievtenant, 160 men, burthen 5 I 2 tun.

I4. Mary Rofe, Captaine Fox Captaine, roo men, burthen 32 I tun.

15. Expedition, Captaine Wake Captaine, Ioo men, burthen 301 tun.

I6. Greyhound, Captaine Wheler Captaine, 50 men, burthen 126 tun.

49 A member of a good family in the Ifle of Wight, where he retired when put out of his command on the navy declaring againft the King. During the King's imprifonment in that ifland he chanced to be at Newport, where he heard an account, probably much exaggerated, of the indignities which the King had to fuffer, " and was fo much tranfported with ..... fury, heing a man of more courage than of prudence or circumfpection, that he caufed a drum to be prefently beaten, and put himfelf at the head of the people who flocked togethur, and cried, "For God, the king, and the people!" and faid " he would lead them to the Caftle and refcue the king from his captivity." Captain Burley was, for this rafh act, tried for high treafon, and fuffered the extreme penalty of the law.-CLarendon's Hift. p. 629 . 


\section{Merchant Ships.}

I. In the Martane, Captaine George Martaine Captaine, Mafter Hakriger Lievtenant, 210 men, burthen 700 tun.

2. Samfon, Captaine Afhly Captaine, Mafter Andrew Lievtenant, I 80 men, burthen 600 tun.

3. Cxear, Captaine Elias Jorden Captaine, Mafter Norton Lievtenant, I 80 men, burthen 600 tun.

4. London, Captaine John Stephens Captaine, Mafter Pomroy Lievtenant, 180 men, burthen 600 tun.

5. Unicorne, Captaine Edward Johnfon Captaine, I 43 men, burthen 475 tun.

6. Mary Flower, Captaine Peter Andrews Captaine, I2I men, burthen 450 tun.

7. Bonny Venter, Captaine George Swanly Captaine, 120 men, burthen 400 tun.

8. The Profperous, Captaine William Driver Captaine, 120 men, burthen 400 tun.

9. Hurclens, Captaine Mover Captaine, $150 \mathrm{men}$, burthen 350 tun.

I0. Paragon, Captaine Leonard Harris Captaine, 105 men, burthen 350 tun.

I I. Hopefull Luke, Captaine Lee Captaine, 105 men, burthen 350 tun.

I2. Golden Angell, Captaine Walker Captaine, 105 men, burthen 350 tun.

13. Exchange, Captaine Lucas Captaine, 89 men, burthen 325 tun.

I4. Mayden-head, Captaine Lewton Captaine, 90 men, burthen 300 tun.

I5. Providence, Captaine William Swandly Captaine, 8 I men, burthen $27 \mathrm{I}$ tun.

I6. Jocelyn, Captaine Partridge Captaine, 60 men, burthen 200 tun. 
His Majesties Ships for the Irish Seas.

I. The Swalow, Captaine Thomas Kettley, I 50 men, r60 tun.

2. Bonny Venture, Captaine Henry Stradling, r6o men, 557 tun.

\section{Merchant S:ips.}

I. Difcovery, Captaine John Brok-haven, I 44 men, 380 tun.

2. Ruth, Captaine Robert Conftable, I 20 men, 400 tun.

3. Employment, Captaine Thomas Afiy, I 32 men, 440 tun.

4. Peter, Captaine Peter Stroung, 8 I men, 270 tun.

5. Pennington, Captaine Jofeph Jordan, 300 men, I 35 tun.

6. Fellowghip, Captaine Thomas Colle, 87 men, 290 tun.

7. Mary, Captaine William Capell, 30 men, 163 tun.

8. John, Captaine John Thomas, 15 men, 50 tun.

The Names of the Orthodox Divines, prefented by the Knights and Burgeffes of Severall Counties, Cities, and Burroughs, as fit perfons to be confulted with by the Parliament, touching the Reformation of Church-Government and Liturgie, Aprill, 25, 1642.

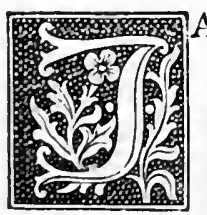

AMES Archbighop of Armagh. Doctor Stiles, Parfon of St. Georges necre the Bridge, prefented by the Burgeffes for the Univerfitie of Oxford.

Doctor Brownrigge, Mafter of Katherine Hall. by the Burgefles for the Univerfitie of Cambridge.

Doctor Twift. William Reyner, prefented for Berkfhire. 
[NAMES OF ORTHODOX DIVINES.] 6I

Henry Wilkinfon. Thomas Valentine, prefented for Buckinghamfhire.

Thomas Dillingham. Oliver Boles, prefented for Bedfordfhire.

Docfor Thomas Wincope. Mafter Thomas Goodwyn, prefented for Cambridgefhire.

Doctor Hoyle. Mafter Bridges of Yarmouth, prefented for Cumberland.

Mafter Gamon. Mafter John Hicks of Lawrick, prefented for Cornwall.

Doctor Innefton. Mafter William Morton, prefented for Durham. Mafter Levir of Rippon. Mafter Michlethwaite of Cherry Burton, prefented for Eboracens.

Stephen Marfhall of Finchfield. Obediah Sedgewick of Cogfhall, prefented for E[jex.

Mafter William Mewe of Eftington, B.D. Mafter John Duninge of Coldafton, prefented for Gloucefterfhire.

Mafter John Greene of Pencombe. Mafter Stanley Gower of Brakton, prefented for Hereford.

Dodtor Smith of Barkway. Doktor Burgefle of Waterford, prefented for Hertford]hire.

Mafter Thomas Bathurft. Mafter Philip Nye, prefented for Huntington.

Mafter Francis Tailor. Mafter Wilfon of Otham, prefented for Kent.

Mafter Edward Calamy of the Parifh of Aldermanbury. Mafter George Walker of St. John's Parifh. Mafter Caroll of Lincolnes Inne. Mafter Lazarus Seaman of Alhallowes Bredftreete, preSented for London.

Anthony Tuckney of Bofton. Thomas Coleman of Blyton, prefented for Lincolne.

Doctor Harris Warden of Winchefter Colledge. Mafter Morley, prefented for Munmouth.

Doctor Downing of Hackney. Mafter Jeremiah Burroughes, prefented for Middlefex. 
Mafter Reignolds Parfon of Branfton. Mafter Hill Parfon of Titchmarfh, prefented for Northampton.

Mafter John Jackfon of Grayes Inne. Mafter William Carter of London, prefented for Northumberland.

Mafter Thomas Thoroughgood. Mafter John Arrowfmith, prefented for Norfolk.

Doctor Sanderfon of Boothby. Mafter John Foxcroft of Gotham, prefented for Nottingham.

Mafter Robert Harris, B.D. Parfon of Hanwell. Mafter Robert Crofje, B.D. fellow of Lincolne Colledge, prefented for Oxford.

Mafter Samuel Gibfon. Mafter Jeremie Whittaker, prefented for Rutland.

Mafter Samuel Crook of Wranton, B.D. Mafter John Connant of Livington, B.D. prefented for Somerfet.

Mafter Thomas Young of Stowmarket. Mafter John Phillips of Wrentham, prefented for Suffolke.

John Langley, Rector of Weftudeley. Chriftopher Tifdale, Rektor of Uphufborne, prefented for Southampton.

Doctor Staunton of Kingefton. Doctor Featly of Lambeth, prefented for Surrey.

Mafter Edward Corbet of Oxford, M. of Arts. Mafter Samuel Hilder/ham, prefented for Salop.

Francis Cook of Yoxhall, Clerk. John Lightfoot of Afhley, Clerk, prefented for Stafford.

Mafter Benjamin Pickering. Mafter Henry Nye, prefented for Suffex.

Mafter Arth. Salway. Doctor Prideaux, Bifhop of Worcefter, prefented for Wigorn.

Mafter Henry Hall, B.D. Mafter Henry Hutton, Mafter of Arts, prefented for Weftmerland.

Henry Seuder, Rector of Collingborne. B.D. Thomas Baily, Rector of Manningford, B.D. prefented for Wiltshire.

Mafter Burgeffe, Parfon of Sutton Ulfield. Mafter Richard Vines, Parfon of Weddington, prefented for Warwick. 
[NAMES OF ORTHODOX DIVINES.] 63

Mafter Richard Buckley, B.D. for Anglefey.

Doctor Temple of Batterfey, for Brecknoc.

Mafter Shute of Lumberftreet, for Cardigan.

Mafter Nicholfon, for Carmarthen.

Mafter Cattarne, for Carnarvan.

Ric. Lloide D.D. for Denbigh.

Doctor Chriftopher Pafhley, for Flint.

Henry Tozer, B.D. and Jenior Fellow of Ex. Colledge, for Glamorgan.

Mafter William Spurftoe, for Merioneth.

Mafter Francis Channell, for Pembroke.

Meedw. Ellis, Rector of Guilsfeild, for Montgome.

Do\&t. Hatchet, for Radnor.

Ifles of Garnfey and Jerfey, Samuel de la Place. Jo. de la March.

The Commiffioners of the generall Affembly have chofe 3 Elders and 6 Minifters to be at this Affembly. The Minifters are Mr. Hinderfon, Mr. Duglafe, Mr. Rutherfurd, Mr. Bayly, Mr. Gelaspe, and Mr. Borthvicke, who is at London. The Elders are the Earl of Caffels, L. Maitland, \& Sr Archib. Johnftone. 


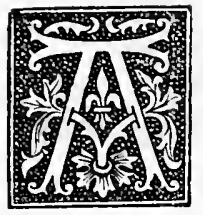

Ireland.

LIST of the Field-Officers chofen and appointed for the Irifh Expedition, by the Committee at Guild-Hall London, for the Regiments of 5000 foot and 500 horfe; Under the Command of PHILIP Lord Wharton, Baron of Scarborough, Lord Generall of

Troops of Horse.

Colonell Generalls Troop.

Captain, Ralfe Whiftler.

Cornet, Peter Ware.

Quarter-mafter, Nicholas Batterfby.

Corporals $\left\{\begin{array}{l}\text { Conyers Cooper. } \\ \text { Bartho. Johnfon. } \\ \text { Ralph Henery. }\end{array}\right.$

Second Troope, Lord Broghill.

Lievtenant, John Allen.

Cornet, Cecill Ajhcough.

Quarter-mafter. Tho. Hudjon.

Corporalls $\left\{\begin{array}{l}\text { Geo. Staples. } \\ \text { Robert Bennet. } \\ \text { Thomas Allen. }\end{array}\right.$

Third troop, Sir Faithfull Fortefcue.

Lievtenant, Francis Dovet. Cornet, Tho. Fortefcue.
Quarter-mafter, Jo. Coyfhe. Corporals $\left\{\begin{array}{l}\text { Jo. Vangerich. } \\ \text { Jo. Marjhall. } \\ \text { Ralph Walcot. }\end{array}\right.$

Fourth troop, Liev. Colonel Jo. Hurry.

Lievtenant, William Mercer.

Cornet ...... Sedefcue.

Quarter-mafter, Jo Pearne.

Corporals $\left\{\begin{array}{l}\text { Ralph Vickerman. } \\ \text { Rich. Whymper. } \\ \text { Will. Crane. }\end{array}\right.$

Fifth troop, Alexander Nayrne. Lievtenant, William Hyde. Cornet, Marmaduke Cooper. Quarter-mafter, Gideon Lock. Corporals $\left\{\begin{array}{l}\text { Nath. Walmfley. } \\ \text { Hugh Farr. } \\ \text { Ben. Ballard his }\end{array}\right.$ Enfigne. 
Sixth troop, Jo. Trenchard.

Lievtenant, Adam Baynard.

Cornet, Jo. Hyde.

Quarter-mafter, Francis Fook.

Corporals $\left\{\begin{array}{l}\text { Jo. Freake. } \\ \text { Jo. Starkey. } \\ \text { Tho. Gwalter. }\end{array}\right.$
Seventh troop, William St. Leger. Lievtenant, Ed. Leventhorp. Cornet, ..... Skrynfheere. Quarter-mafter, Philip Vanderhiden.

Corporals $\left\{\begin{array}{l}\text { Ed. Gray. } \\ \text { Nicho. Phipp. } \\ \text { Robert Wood. }\end{array}\right.$

\section{Foot Companies.}

Colonell Generall.

His Captain, Edward Mafy.

His Enfigne, Oliver Cromwell. ${ }^{50}$ Lievtenant Colonell and Sergeant Major Generall, Jeremy Horton.

His Lievtenant, Tho. Browne. His Enfigne, Ed. Greene. Serjeant Major, Owen Parry. His Lievtenant, Ed. Browne. His Enfine, Rob. Hughes. Firft Captain, Vincent Calmady. his Lievtenant, Edward.Tyrer. his Enfigne, Richard Bland. Second Captain, Robert Long. his Lievtenant, Tho. Allanby. his Enfigne, Roger Moore.
Third Captain, Henry Carew. his Lievtenant, Charles Holcroft.

his Enfigne, William Heyden. Fourth Captain, Henry Skipwith.

his Lievtenant, Jo. Ivey. his Enfigne, Oliver St. John. Fifth Cap. of Fire-Locks, Elias

Struice.

his Lievtenant, Ed. Gray. his Enfigne, Tho. Barber.

Second Colonell, Lord Kerry. his Lievtenant, Robert Hamond. his Enfigne, Richard Bagot.

so Afterwards Lord Protector. From this entry it is evident that Oliver Cromwell, before being a colonel of horfe, had held a commifion in a foot regiment. The earlieit copy of this lift of "Field Officers for the Irifh Expedition" that I lave feen is a broadfide in the Britifh Mufeum, (66g. f: 6). "London Printed for Edward Paxton, June $11,1642 . "$ See further, in proof of Oliver Cromwell once having been a foot foldier, in Notes and Queries, Second Series, vol. xii. p. 285 . 
Lievtenant Colonell, Henry Shelley.

his Lievtenant, Jo. Ramsford. his Enfigne, Jo. Afhfield.

Sergeant Major, Daniel Good-

rick.

his Lievtenant, Geo. Lower. his Enfigne, Charles Blount. Firft Captain, Charles Dawfon. his Lievtenant, Philip Meautas.

his Enfigne, Jacob Stringer. Second Captaín, Herbert Blankchard.

his Lievtenant, Morgan Tinney.

his Enfigne, Chriftoph. Chudleigh.

Third cap. Agmondifham Murfchamp.

his Lievtenant, Will. Dothwait.

his Enfigne, Gervafe Brach. Fourth Captain, Paul Wats. his Lievtenant, Andr. Manwarring.

his Enfigne, Tho. Barriffe. Fifth Capt. for Firelocks, Wil. Lower.

his Lievtenant, . . . Redman. his Enfigne, Jo. Raymond.

Third Colonell, Tho. Ballard. his Lievtenant, Tho. Grover. his Enfigne, Leonard Morton. Lievtenant Colonell, Sir Ed.

Denny.

his Lievtenant, Ed. Odingfells. his Enfigne; William Garfoot. Sergeant Major, Francis Martin.

his Lievtenant, Rob. Noyce. his Enfigne, Jo. Hardy.

Firft Captain, Captain Primrofe. his Lievtenant, Edward Norbury.

his Enfigne, William Fowlis. Second Captain, Edward Allen.

his Lievtenant, Fran. Bowyer. his Enfigne, Robert Goodwin. Third Captain, Fran. Fook.

his Lievtenant, Tho. Nayerne. his Enfigne, Hen. Higgins. Fourth Captain, Thomas Middleton.

hís Lievtenant, Jo. Lookar. his Enfigne, Charles Parker. Fifth Captain for Firelocks, Pet. Nurford.

his Lievtenant, Robert Davis. his Enfigne, Hen. Cope.

Fourth Colonell, Charles Effex. his Lievtenant, Fran: Hall. his Enfigne, Jo. Shipman. Lievt. Col. Adam Cunningham. his Lievtenant, Peter Crifpe. 
his Enfigne, Leonard Hawkins.

Sergeant Major, Tho. Ogle. his Lievtenant, James Webb. his Enfigne, Richard Ofborne. Firft Captain, William Roberts. his Lievtenant, Ambrose Tindall.

his Enfigne, Jo. Watkins. Second Captain, George Narrow. his Lievtenant, Edward Barnwell.

his Enfigne, Tho. Paramour. Third Captain, Conftance Ferrer. his Lievtenant, William Hewet.

his Enfigne, Jo. Hemings. Fourth Captain, Sam. Loftus. his Lievtenant, James Barrell. his Enfigne, Fran Butler. Fifth Cap. for Firelocks, John Jinkins.

his Lievtenant, Bartho. Elecot.

his Enfigne, Mr. Wayte.

Fifth Colonell, William Bamfield.

his Captain, Sam Price. his Enfigne, .... Cafworth. Lievtenant Colonell, ... W Wagftaffe.

his Lievtenant, Tho. Coleby. his Enfigne, Robert Nelfon.

Sergeant Major, George Hutchinfon.

his Lieutenant, Jo. Minfhaw. his Enfign, William Bourcher. Firft Captain, Jo. Bainfield. his Lievtenant, Richard Bingley.

his Enfign, Ralph Garts. Second Captain, Horatio Carey. his Lievtenant, Allen Povey. his Enfigne, Humfrey Burton. Third Captain, Robert Baker. his Lievtenant, Michael Bland.

his Enfigne, Jo. Rofe. Fourth Captain, Chriftoph. Burgh. his Lievtenant, Tho. Hoare. his Enfigne, Samuel Manaton. Fifth Cap. for Firelocks, Rich. Benfon. his Lievtenant, Tho. Latimer. his Enfigne, Jo. Browne. 
CHISWICK PRESS :- PRINTED BY WHITTINGHAM AND WILKJNS, TOOKS COURT, CHANCERY LANE. 


\section{Curious and Interefting Books}

\section{worthy of Notice.}

Now ready, in $\int \mathrm{m} .4^{t}$ to. half morocco, very choicely printed by Whittingham and Wilkins, with floreated capitals, price 7 s. 6 d.

\section{HE MYSTERY OF THE GOOD OLD}

CAUSE : Sarcaftic Notices of thofe Members of the LONg ParLIAMENT that held Places, both Civil and Military, contrary to the Self-denying Ordinance of April 3, 1645; with the Sums of Money and Lands they divided among themfelves.

Gives many curious particulars about this famous Affembly not mentioned by hiftorians or biographers. It has juft been very carefully reprinted from the exceffively rare original. The hiftory of almoft every county in England receives fome illuftration from it. Genealogifts and antiquaries will find in it much interefting matter.

Now ready, 12 mo., in binding after a pattern of the period, very choicely printed by Whittingham and Wilkins, price 6s. $6 d$.

\section{The earliest known London Directory.}

\section{A COLLECTION OF THE NAMES OF THE MER-} CHANTS LIVING IN AND ABOUT THE CITY OF LONDON; Very Ufefull and Neceffary. Carefully Collected for the Benefit of all Dealers that thall have occafion with any of them; Directing them at the firf fight of their name to the place of their abode.

London: printed for Sam. Lee, 1677 .

This curious little volume has been reprinted verbatim from one of the only two copies known to' be in exiftence. It contains a hort Introduction, pointing out fome of the principal perfons mentioned in the lift. For hiftorical and genealogical purpofes the little book is of the greateft value. This is what the London Review faid of it, when announcing the intended republication:- "Of the only two known copies, one is preferved in the Free Library at Manchefter, and the other, imperfect, was fold a thort time fince at the fale of the late Rev. Jofeph Hunter's Library, at Mefrrs. Sotheby and Wilkinfon's ; it produced $9 l$., and was purchafed, we believe, for the Britifh Mufeum. The little book is curious, among other things, as containing the name of Alexander Pope, the father of the poet, among the merchants refiding in Broad Street. It was in this thoroughfare that the poet, in all probability, was born. The crooked-backed little genius-like moft human diminutives-was a vain man. When people at Twickenham, or at Button's Coffee-houfe in Covent Garden, talked to him about his father, he generally fpoke of their old City houfe as fomewhere down in Lombard Street, amongit the baronets and aldermen who kept banks and offices of exchange about there. Pope liked the idea of his father keeping fuch excellent and lofty company, and probably, for this reafon, never mentioned Broad Street. The little oldfafhioned ' Directory,' however, has told the true tale. The names of the Meffrs. Hoare, the eminent bankers of Fleet Street, at the fign of the ' Leathern Bottle '- the houfe, by the way, where Oliver Cromwe!! kept his money-occurs in the Directory, as do alfo thofe of the Meffrs. Child, the well-known bankers of Temple Bar." ONLY A very FEW copies HAVE BEEN REPRINTED ON PAPER MADE TJ RESEMBLE THE ORIGINAL. 


\section{CURIOUS AND INTERESTING BOOKS}

Nowe ready, price 5s.; by poft, on roller, .5s. 4d.

MAGNA CHARTA. An Exact Facfimile of the Origina

Document, preferved in the Britifh Mufeum, very carefully drawn, and printed or fine plate paper, nearly 3 feet long by 2 wide, with the ARMS AND SEALS OF THI BaRONS ELABORATELY EMBLAZONED IN GOLD AND COLOURS. A.D. 1215.

CoPIED BY EXPRESS PERMISSION, and the only correct drawing of the Great Charter ever taken. This important memorial of the liberties and rights of Englifhmen is admirably adapted for framing, and would hang with propriety from the walls of every houfe in the country. As a guarantee to the purchafer that the facfimile is exact, the publifher need onl ftate that Sir Frederick Madden has permitted copies to hang for public infpection upon thi walls of the Manufcript Department in the Brition Mufeum. It was executed by Mr Harrifon, under whofe aufpices the fplendid work on the Knights of the Garter was pro. duced fome years ago. HANDSOMELY FRAMED AND GLAZED, IN CARVED OAK, OF. AN ANTIQUI PATTERN, 22s. 6d. It is uniform witb the "Roll of Battle Abbey."

A Full. Translarion, with Notes, has juft been prepared, price $6 d$. It has been ven beautifully printed on a large fheet of tinted paper by Meffrs. Whittingham and Wilkins It may be framed and hung befide the original, or can be pafted at the back, according to the tafte of the purchafer.

Now ready, uniform with "MAGNA CHARTA," price 5s.; by poft, on roller, 5s. 4 d. ROLL OF BATTLE ABBEY; or, a List of THE PRINCIPAL WARRIORS WHO CAME OVER FROM NORMANDY WITH WILLIAM THE CONQUEROR, AND SETTLED IN THIS CoUNTRY, A. D. 1066-7, from Authentic Documents, very carefully drawn, and printed on fine plate paper, nearly 3 feet long by 2 feet wide, with the ARMS OF THE PRINCIPAL BARONS ELABORATELY EMBLAZONED IN GOLD AND COLOURS.

A MOST currous DOCUMENT, and of the greateft intereft, as the defcendants of nearly all] thefe Norman Conquerors are at this moment living amongft us, bearing the old Anglo. Norman name, nightly altered, but little dreaming of the relationhip betwixt them and the bold warriors who fought and won at Haftings nearly a thoufand years ago. The writing, of the period, is very legible. No names are believed to be in tbis "Battel Roll" which are not fully entitled to the diffinction. HANDSOMELY FRAMED AND GLAZED, IN CARVED OAK, OF AN ANTIQUE PATTERN, price 22s. $6 d$.

Now ready, in 4 to., very handfomely printed, with curious woodcut initial letters, by Whittingham and Wilkins, half cloth, gs. 6d.; or, half morocco, very neat, I Is. $6 d$.

\section{ROLL OF CARLAVEROCK; with the ARMS OF THE}

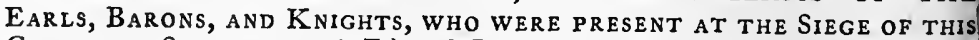
CASTLE IN SCOTLAND, 28 Edward I., A.D. 1300 ; including the ORIGINal Anglo-Norman Poem, and an Englifh Tranfation of the MS. in the Britifh Mufeum; the whole newly edited by Thomas Wright, Ese., M.A., F.S.A.

A very handfome volume, and a delightful one to lovers of Heraldry, as it is the earlief blazon of arms known to exiff. "It contains the accurate blazon of above one hundred Knights or Bannerets of the reign of Edward I., among whom were the King, the Prince of Wales, and a greater part of the Peers of the realm;" thius affording evidence of the perfeet ftate of the Science of Fieraldry at that early period. THE ARMS ARE EXQUISITELY EMARLAZONED IN GOLD AND COLOURS. 


\section{Now ready, price $2 s . ;$ by poft, on roller, $2 s .4 d$. \\ VARRANT TO EXECUTE CHARLES I.-An Exact}

Facfimile of this Important Document in the Houfe of Lords, with the FIFTYNine Signatures of the Regicides, and Correfponding Seals, admirably executed on paper made to imitate the Original Document, 22 in. by 14 in.

Copied BY EXPREsS PERMission. - King Charles I., January 2oth, 1648 , was brought from St. James's to Sir R. Cotton's houfe (now the Speaker's refidence), and was four days arraigned at the bar of the Houfe of Commons by Bradshaw, and feventy-nine Judges Commiffioners, named for his Trial. The original document was kept in the Old Houfe of Peers' Library, and being faved from the Fire, was preferved in the Poet's Tower, and is now under the librarian's care at the Houfe of Lords. Some of the Regicides died in America, while many of the children of thofe executed at the Reftoration betook themfelves to that country, and laid the foundations of many of the firf families in New England. HAND. SOMELY FRAMED AND GLAZED, IN CARVED OAK, OF AN ANTIQUE PATTERN, 14s. $6 d$.

$$
\text { Now ready, fafe on roller, 2s.; by poft, } 2 s .4 d \text {. }
$$

\section{VARRANT TO EXECUTE MARY QUEEN OF} SCOTS.-The Exact Facfimile of this Important Document, including the Signature of Q. Elizabeth and Facfimile of the Great Seal, on tinted paper, made to initate the Original $M S$.

"I praife and thank my God, that it pleafes Him to put an end by this to the many miferies and calamities that they have compelled me to endure; for, fince nineteen years up to the prefent moment, I have been conftituted a prifoner, and very evilly entreated by the Queen of England, my fifter, without ever having injured, as God is my principal witnefs." Mary's Reply to my Lord Beale, wobo was commifioned to inform ber of Elizabetb's Sentence of

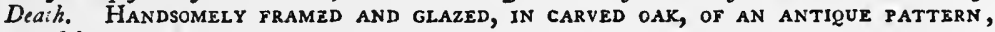
14s. $6 d$.

Now ready, only a few copies for fale, original price 5s., now offered at $2 s .6 d$., a ICTIONARY OF THE OLDEST WORDS IN THE ENGLISH LANGUAGE, from the Semi-Saxon Period of A.D. 1250 to 1300 , confifting of an Alphabetical Inventory of EVERY WORD FOUND IN THE PRINTED English Literature of THE I3TH Century, by the late HerberT Coleridge, Secretary to the Philological Society. 8roo., neat.

An invaluable work to hiftorical ftudents and thofe interefted in linguiftic purfuits. "The prefent publication may be confidered as the foundation-ftone of the Hiftorical and Literary Portion" of the great ENGLish Dictionary now in preparation by the Philological Society. "Explanatory and etymological matter has been added, which, it is hoped, may render the work more generally interefting and ufeful than could otherwife have been the cale."

Now ready, in cloth extra, (only a ferw copies for fale,) price i 5 s.

\section{HE NOBLE AND GENTLE MEN OF ENGLAND,} or Notes touching the Arms and Defcents of the Ancient Knightly and Gentle Houfes of England, arranged in their refpective Counties, attempted by EVELYN Philip ShirLey, Efq., M.A., F.S.A., one of the Knights of the Shire for the County of Warwick, 4to., HANDSOMELY PRINTED, PP. 321 , with numerous heraldic illuftrations.

A very interefting work on the Englinh Families now exifting, that were regularly eftablithed either as knigbily or gentle houfes before 1500 . It notices alfo the ancient and prefent eftates of thefe county families. The work poffeffes confiderable value to thofe who are interefted in genealogical and heraldic ftudies. 


\section{HERALDRY OF WALES.}

Only 50 copies, in marvellous facfimile, 4to., on old Welfh paper, hf. morocco, 12s. 6 d.

DISPLAY OF HERAULDRY of the particular COAT ARMOURs now in Ufe in the Six Counties OF NORTH WALEs, and feveral others Flfewhere; with the NAMES of the FAMILIES, whereby any Man knowing from what Family he is defcended, may know his particular ARMS. By JoHN REYNOLDS, of OSWESTRY, ANTIQUARIAN; WITH NEARLY ONE HUNDRED COAT ARMOURS BLAZONED IN THE OLD STYLE.

Chefter, printed $\mathbf{1 7 3 9 .}$

FROM A UnIQUe copy, of pricelefs value to the lover of Heraldry and Genealogy. The work on Welf Family Hiffory, iffued privately by this author in the fame year, is comparatively common, yet copies of this have realized twenty guineas. A few copies have been taken off in marvellous facfimile, on old Welm paper. They have coft more than the price afked. THE OWNER CHALLENGES ANY FACSIMILE-EXPERT OR ARTIST IN THIS COUNTRY OR XLSEWHERE, TO PRODUCE ANY THING MORE LIKE UNTO A VERITABLE OLD BOOK THAN THIS. Photozincography is a thallow pretence when compared with it.

\section{The Family History of the English Counties.}

Now ready, in 8vo., on tinted paper, nearly $35^{\circ}$ pages, very neat, price 5s., a

\section{DESCRIPTIVE ACCOUNT OF TWENTY-THOU-}

SAND MOST CURIOUS AND RARE BOOKS, OLd TRACTS, ANCIENT Manuscripts, Engravings, and Privately Printed Family Papers, relating to the Hiftory of almolt every LANDED ESTATE and OLD ENGLISH FAMILY in the Country; interfperfed with nearly Two-thoufand Original Anecdotes, Topographical and Antiquarian Notes, by John Camden HotTen.

By far the largest Collection of English and Welsh Topography and Familt HISTORY EVER FORMED. Each article has a fmall price affixed for the convenience of thofe who may defire to poffefs any book or tract that interefts them.

Now ready, fqr. 8vo., exquifitely printed on tinted paper, price ros. 6 d. only.

COMMON PRAYER. Facfimile of the Prayer Book of Queen Elizabeth, adapted to the prefent Reign, with wood-engravings of ALBERT DURER's "Life of Chrift," rich woodcut Border on every page of Fruit and Flowers; alfo the DANCE of DEATH, a fingularly curious feries after HoLBEIN, with Scriptural Quotations and Proverbs in the Margin.

Tbis edition has been prepared exprefsly for Mr. Hotten. All the LATEsT alterations in the Common Prayer Book of our Eftablifhed Church are given. Several new and moft curiouny engraved woodcut borders have been added. It is only neceffary to remark that the old edition, without thefe improvements, fold for One Guinea per copy.

LONDON: JOHN CAMDEN HOTTEN, I5I, PICCADILLY. W. 




